\title{
Northern Iberian abrupt climate change dynamics during the last glacial cycle: A view from lacustrine sediments
}

\author{
Ana Moreno ${ }^{\mathrm{a}, *}$, Penélope González-Sampériz ${ }^{\mathrm{a}}$, Mario Morellón ${ }^{\mathrm{a}, \mathrm{b}}$, Blas L. Valero-Garcés ${ }^{\mathrm{a}}$, \\ William J. Fletcher ${ }^{c}$ \\ ${ }^{a}$ Department of Geoenvironmental Processes and Global Change, Pyrenean Institute of Ecology - CSIC, Avda. Montañana 1005, 50059 Zaragoza, Spain \\ ${ }^{\mathrm{b}}$ Department of Geographical and Earth Sciences, University of Glasgow, East Quadrangle, University Avenue, Glasgow G128QQ United Kingdom \\ ${ }^{\mathrm{c}}$ Institute of Geosciences, Goethe-Universität, Frankfurt am Main 60438, Germany
}

\section{A R T I C L E I N F O}

\section{Article history:}

Received 9 March 2010

Received in revised form 18 May 2010

Accepted 11 June 2010

Available online 14 July 2010

\begin{abstract}
A B S T R A C T
We present a palaeoclimatic reconstruction of the last glacial cycle in Iberia (ca. 120,000-11,600 cal yrs BP) based on multi-proxy reconstructions from lake sediments with robust chronologies, and with a particular focus on abrupt climate changes. The selected lake sequences provide an integrated approach from northern Iberia exploring temperature conditions, humidity variations and land-sea comparisons during the most relevant climate transitions of the last glacial period. Thus, we present evidence that demonstrates: (i) cold but relatively humid conditions during the transition from MIS 5 to MIS 4, which prevailed until ca. 60,000 cal yrs BP in northern Iberia; (ii) a general tendency towards greater aridity during MIS 4 and MIS 3 (ca 60,000 to 23,500 cal yrs BP) punctuated by abrupt climate changes related to Heinrich Events (HE), (iii) a complex, highly variable climate during MIS 2 (23,500 to 14,600 cal yrs BP) with the "Mystery Interval" (MI: 18,500 to 14,600 cal yrs BP) and not the global Last Glacial Maximum (LGM: 23,000 to 19,000 cal yrs BP) as the coldest and most arid period. The last glacial transition starts in synchrony with Greenland ice records at $14,600 \mathrm{cal}$ yrs BP but the temperature increase was not so abrupt in the Iberian records and the highest humidity was attained during the Allerød (GI-1a to GI-1c) and not during the Bølling (GI-1e) period. The Younger Dryas event (GS-1) is discernible in northern Iberian lake records as a cold and dry interval, although Iberian vegetation records present a geographically variable signal for this interval, perhaps related to vegetation resilience.
\end{abstract}

(c) 2010 Elsevier Ltd. All rights reserved.

\section{Introduction}

The last glacial cycle (ca. 120,000-11,600 cal yrs BP) was a dynamic period when rapid climate changes, called Dansgaard/ Oeschger $(\mathrm{D} / \mathrm{O})$ cycles and characterized by abrupt warming and gradual cooling, occurred with a periodicity of ca. 1450 years (Wolff et al., 2010). Understanding the response of different ecosystems to these rapid climatic events is of special interest in the context of present-day global warming but, unfortunately, the mechanism behind rapid climate oscillations, the teleconnections that transfer the signal all around the globe, and the impacts of rapid climate changes on terrestrial and marine ecosystems are still far from being totally understood (Broecker, 2000). In fact, it is known that

\footnotetext{
* Corresponding author.

E-mail addresses: amoreno@ipe.csic.es (A. Moreno), pgonzal@ipe.csic.es (P. González-Sampériz), mariomm@ipe.csic.es, mario.morellon@ges.gla.ac.uk (M. Morellón), blas@ipe.csic.es (B.L. Valero-Garcés), w.fletcher@em.uni-frankfurt.de (W.J. Fletcher).
}

some of the climate events of the last glacial cycle were not synchronous, such as the timing for the maximum glacier advance at different latitudes (Hughes and Woodward, 2008; Clark et al., 2009), but the causes remain unexplained. In particular, the last glacial-interglacial transition (LGIT, 15,000-9000 cal yrs BP) has a special interest since many processes and components of the climate system were involved in a total restructuring of the climate at a global scale. That transition occurred in several steps, some of them still poorly known in terms of their hydrological signal or internal structure, such as the Mystery Interval (MI) (17.5-14.5 cal kyr BP) (Denton et al., 2006). To address all these questions, it is necessary to assess the synchrony or asynchrony between different records from different archives, and this is one of the foci of INTIMATE (INTegration of Ice-core, MArine and TEerrestrial records) group (Hoek et al., 2008).

The Iberian Peninsula (IP) constitutes a key location for answering questions related to the transference of the climate signal from high- to mid-latitudes. The IP is an especially sensitive region to climate changes due to its location at geographical 
(subpolar versus subtropical latitudes) and atmospheric (westerly winds versus north-African influences) boundaries (Moreno et al., 2005; Bout-Roumazeilles et al., 2007). In addition, its location leads to the expression of some of the "cold northern events" during last glacial cycle as "dry southern events", as inferred from dust accumulation (Moreno et al., 2002) and pollen composition in marine cores surrounding the IP (Sánchez-Goñi et al., 2002; Fletcher et al., 2010). It remains necessary to evaluate the precise spatiotemporal nature of terrestrial ecosystem change, as suggested by recent lake (González-Sampériz et al., 2006) and speleothem records (Moreno et al., 2010). Understanding the effects of past abrupt climate changes may help to predict and minimize the impact of future global warming (Costanza et al., 2007) in the IP, one of the most vulnerable areas in the context of the Mediterranean region (Solomon et al., 2007).

Iberian terrestrial records, supported by the study of terrestrial tracers (pollen) in marine cores, have allowed the characterization of the response on land to climate change and the discrimination of local or regional signatures, both necessary tasks to complete and improve the palaeoclimate reconstructions carried out in Europe during the last glacial cycle (e.g., Wohlfarth et al., 2008). Additionally, lakes are systems where changes in water availability can be recorded in the sediments in a more direct way than temperature variations (e.g., Cohen, 2003). Thus, the integration of several proxies (physical properties, sedimentary facies, geochemical composition, diatom and pollen assemblages, etc.), can lead to the reconstruction of past lake levels, and thus to the estimation of precipitation-evaporation balance (e.g., Morellón et al., 2009a). Furthermore, other environmental changes such as vegetation cover and land use can be inferred from palynological studies (Morellón et al., in press; Rull et al., in press). Lake sediments can often provide continuous, high-resolution records with robust chronologies, thus providing detailed and comprehensive palaeoenvironmental reconstructions.

The study of Iberian Quaternary lake sequences with the aim of reconstructing palaeoclimatic or palaeoenvironmental conditions is rooted in the long history of sedimentological studies of pre-
Quaternary formations (Cabrera and Anadón, 2003; Valero-Garcés, 2003). However, only recently and thanks partly to new technical improvements (both in the field and laboratory) and to the consolidation of new Spanish research groups, has climate reconstruction been tackled using a multi-proxy strategy and robust chronological frameworks. Thus, the number of palaeoclimate studies from lake records in the IP has markedly increased as well as the quality of the records, in terms of their continuity, chronological accuracy, effective temporal resolution and the range of analytical methods combined (Valero-Garcés and Moreno, in press). We consider a review of the key published data timely because, since lake response to climate is non-linear, it is critical to synthesize large data sets to distinguish clearly local influences from broad-scale regional patterns (Fritz, 2008). In addition, we highlight the most critical gaps in the information (in terms of both spatial and temporal coverage) to help plan future research in the IP.

\section{Study sites}

The purpose of this paper is not an exhaustive compilation of last glacial Iberian lake records but a summary of the most recent work that fulfills the following requisites: (1) the palaeoclimate interpretations are based on multi-proxy reconstructions from lake sediments, including sedimentological description and physical or geochemical data from the lacustrine sequences and not only palynological data as occurs in the case of many well-known studies, and (2) the chronology is independent, robust and accurate, based on calibrated AMS ${ }^{14} \mathrm{C}$ dates, U-Th dating or Optically Stimulated Luminiscence (OSL), if applicable. With the selected records, this study aims to carry out a regional palaeoclimate synthesis (Table 1, Fig. 1) covering the last glacial cycle, since last glacial inception (about $120,000 \mathrm{cal}$ yrs BP) to the onset of the Holocene $(11,600 \mathrm{cal}$ yrs $\mathrm{BP})$. Up to now, none of the available climate reconstructions from southern IP lake records spanning the last glacial and deglaciation intervals is based on a multi-proxy strategy. Thus, Padul peatbog from southeast IP is only based on pollen data for

Table 1

Lake records from the IP reviewed in this paper.

\begin{tabular}{|c|c|c|c|c|c|}
\hline & Coordinates & Lake type & Proxies & Chronology & References \\
\hline \multicolumn{6}{|l|}{ Northern Iberia } \\
\hline 1. Enol Lake & $43^{\circ} 11^{\prime} \mathrm{N} ; 4^{\circ} 09^{\prime} \mathrm{W} ; 1070 \mathrm{~m}$ asl & Karstic - glacial & $\begin{array}{l}\text { PHYS, SED, GEO, } \\
\text { BIO, POL }\end{array}$ & $38-2.5$ cal kyr BP & Moreno et al. (in press-a) \\
\hline 2. Comella Hollow & $43^{\circ} 16^{\prime} \mathrm{N} ; 4^{\circ} 59^{\prime} \mathrm{W} ; 850 \mathrm{~m}$ asl & Karstic - glacial & SED, GEO & Base at 42 cal kyr BP & $\begin{array}{l}\text { Jiménez Sánchez and } \\
\text { Farias (2002) }\end{array}$ \\
\hline \multicolumn{4}{|l|}{ West-Northwestern Iberia } & $25-0$ cal kyr BP & Rico et al. (2007) \\
\hline \multicolumn{6}{|l|}{ Iberian range and Central Iberia } \\
\hline 4. Laguna Grande & $42^{\circ} 02^{\prime} \mathrm{N} ; 3^{\circ} 01^{\prime} \mathrm{W} ; 1500 \mathrm{~m}$ asl & Glacial & SED & 20-0 cal kyr BP & Vegas (2007) \\
\hline 5. Fuentillejo maar & $38^{\circ} 56^{\prime} \mathrm{N} ; 4^{\circ} 3^{\prime} \mathrm{W} ; 635 \mathrm{~m}$ asl & Volcanic & SED, GEO, POL & $700-0$ cal kyr BP & $\begin{array}{l}\text { Vegas et al. (in press) for last } \\
50 \text { cal kyr BP }\end{array}$ \\
\hline 6. Laguna del Hornillo & $41^{\circ} 58^{\prime} \mathrm{N} 2^{\circ} 0^{\prime} \mathrm{W}$ & Glacial & SED & $27-0$ cal kyr BP & Vegas $(2006)$ \\
\hline \multicolumn{6}{|l|}{ Pyrenees and Northeastern Iberia } \\
\hline 7. Banyoles Lake & $42^{\circ} 07^{\prime} \mathrm{N} ; 2^{\circ} 45^{\prime} \mathrm{E} ; 173 \mathrm{~m}$ asl & Karstic & SED, GEO, POL & $30-5$ cal kyr BP & $\begin{array}{l}\text { Pérez-Obiol and Julià (1994), } \\
\text { Valero-Garcés et al. (1998) }\end{array}$ \\
\hline 8. Villarquemado palaeolake & $40^{\circ} 30^{\prime} \mathrm{N} ; 1^{\circ} 18^{\prime} \mathrm{W} ; 987 \mathrm{~m}$ asl & $\begin{array}{l}\text { Tectonic } \\
\text { depression }\end{array}$ & SED, GEO & $120-0$ cal kyr BP & Valero-Garcés et al. (2007) \\
\hline 9. El Portalet peatbog & $42^{\circ} 48^{\prime} \mathrm{N} ; 0^{\circ} 23^{\prime} \mathrm{W} ; 1980 \mathrm{~m}$ asl & Glacial & SED, GEO, POL & $33-5$ cal kyr BP & González-Sampériz et al. (2006) \\
\hline $\begin{array}{l}\text { 10. Saladas de Monegros } \\
\text { (Salineta, La Playa, Mediana...) }\end{array}$ & $41^{\circ} 28^{\prime} \mathrm{N} ; 0^{\circ} 09^{\prime} \mathrm{W} ; 350 \mathrm{~m}$ asl & $\begin{array}{l}\text { Dissolution and } \\
\text { aeolian deflaction }\end{array}$ & SED, GEO, POL & ca $20-0$ cal kyr BP & $\begin{array}{l}\text { Gonzalez-Samperiz et al. (2008) } \\
\text { and references therein }\end{array}$ \\
\hline 11. Ibón de Tramacastilla & $42^{\circ} 43^{\prime} \mathrm{N}^{\circ} 23^{\prime} \mathrm{W} ; 1640 \mathrm{~m}$ asl & Glacial & SED, GEO, POL & $30-0$ cal kyr BP & $\begin{array}{l}\text { García-Ruíz et al. (2003), } \\
\text { Montserrat (1992) }\end{array}$ \\
\hline 12. Estanya Lake & $42^{\circ} 02^{\prime} \mathrm{N} ; 0^{\circ} 32^{\prime} \mathrm{E} ; 670 \mathrm{~m}$ asl & Karstic & PHYS, SED, GEO, BIO & 20-0 cal kyr BP & $\begin{array}{l}\text { Morellón et al. (in press, } \\
\text { 2009a) }\end{array}$ \\
\hline
\end{tabular}

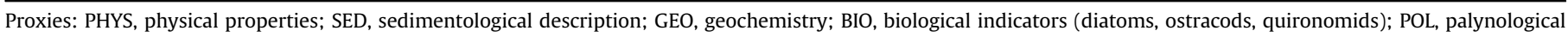
reconstruction. 


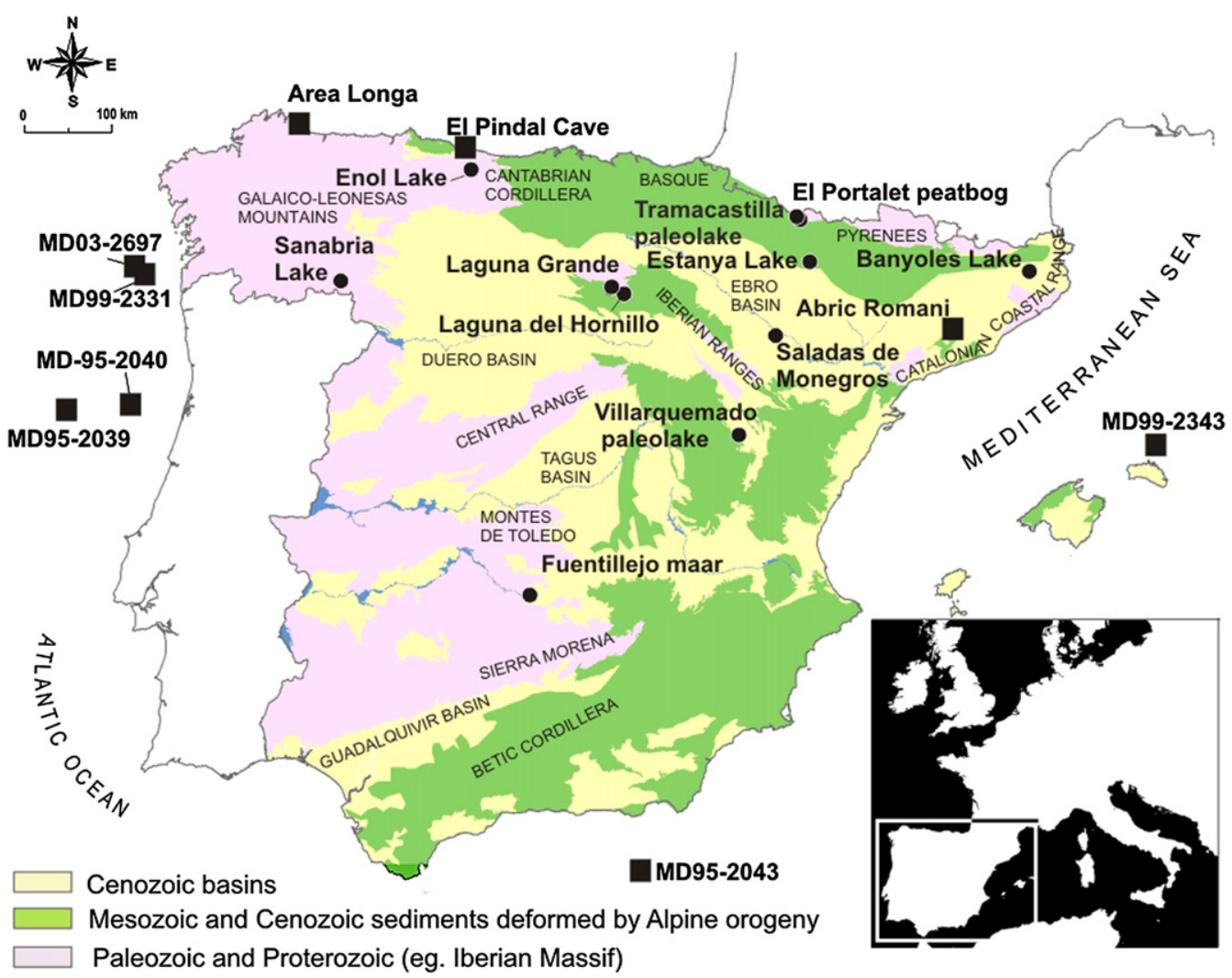

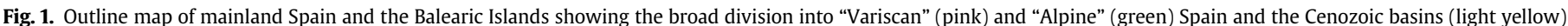

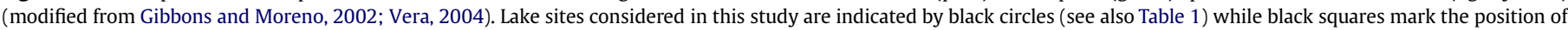

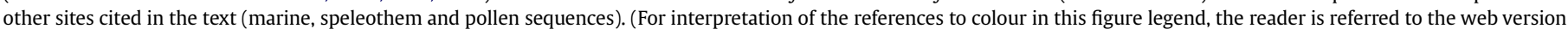
of this article.)

the glacial interval (Pons and Reille, 1988) and the chronology for this interval is not well constrained in the new 107-m long borehole from the same basin (Ortiz et al., 2004). Other multiproxy reconstructions from southern IP span only the Holocene or part thereof (e.g., Laguna de Zoñar; Martín-Puertas et al., 2008). As a consequence, the selected records are distributed mostly across the northern IP, with the exception of Fuentillejo maar, which is located in central Spain (Table 1, Fig. 1).

The geology of the IP is remarkably diverse, but, in a simplistic way, can be divided into three main geological units (Gibbons and Moreno, 2002), although their exact boundaries are still under discussion (Vera, 2004): (1) Palaeozoic and Proterozoic rocks forming the Iberian Massif and the basement of other mountain ranges (e.g., Pyrenees); (2) Mesozoic and Cenozoic sedimentary formations affected by the Alpine orogeny, and mostly constituting the Pyrenees, Betics and Iberian Ranges, and (3) large tectonic Cenozoic basins, such as the Ebro or Tagus basins and other small basins located within the Alpine ranges (Fig. 1). Thus, in northern Iberia, the Pyrenees, Cantabrian Cordillera and Galaico-Leones Mountains constitute the most important orographic features while the central IP is crossed by the Central Range, which divides the central plateau in two northern and southern "mesetas". The Iberian Range, which runs north-west to south-east, constitutes the hydrological divide between the Atlantic and Mediterranean watersheds (Fig. 1). Due to the geographic situation and topographic conditions, the climate of the IP is extremely varied, but roughly, a moderate Continental climate characterizes the inland areas, an Oceanic climate dominates in the north and west and a warm Mediterranean climate is experienced along the Mediterranean coast (Capel Molina, 1981). Both geography and climate critically influence the distribution of vegetation and determine the biogeographical features of all the provinces within the Eurosiberian and Mediterranean regions (Blanco-Castro et al., 1997; Rivas-Martínez, 2007) (see also Fig. 1 in González-Sampériz et al., in press).

Unfortunately, the large geological, climatic and biogeographic diversity of the IP is far from being representatively sampled by the selected lake records included in this work (Table 1 and Fig. 1). Some areas remain poorly covered, such as the central region, due to the lack of multi-proxy studies on the scarce lacustrine systems (cf. Fuentillejo maar; Vegas et al., in press), while other environments are over-represented, such as the montane sectors, due to more abundant permanent, deep lakes, which originated during the last deglaciation (e.g., Enol Lake; Moreno et al., in press-a). To cover some of the gaps, other well-known, relatively long records (e.g., Area Longa in the NW; Gómez-Orellana et al., 2007, or Abric Romaní in the NE, Burjachs and Julià, 1994) are included in the discussion despite the fact that they do not fulfill the palaeoenvironmental criteria established above for site selection since they mainly concern vegetation reconstruction. Furthermore, the last glacial cycle is not homogenously represented by the selected records since lake sequences including MIS 4 or MIS $5 \mathrm{a}-\mathrm{d}$ in the IP are very rare. For these intervals, we support the palaeoclimate discussion with other terrestrial (moraines, speleothems) or marine archives (both represented by black squares in Fig. 1). An exhaustive compilation of pollen records from the IP covering the Pleistocene has been recently published by González-Sampériz et al. (in press). In addition, a new issue of Journal of Paleolimnology (Valero-Garcés and Moreno, in press) includes a good compilation of papers based on Iberian lake records, though mostly focused on the Holocene. 


\section{Methods}

An important advance in palaeoclimate reconstruction based on lake records in the IP has been the consistent application of a multiproxy methodology, following the PAGES strategy and the procedure implemented, among others, by the Limnological Research Center from the University of Minnesota (http://lrc.geo.umn.edu). This procedure starts with the Initial Core Description (ICD) including non-destructive measurement of physical properties (usually carried out by a multi-sensor core logging GEOTEK and including the measurement of magnetic susceptibility -MS-, bulk density, etc.), core splitting into working and archive halves, imaging of the core sections, and macro- and microscopic identification of sedimentary structures and composition using visual and microscopic observations (Schnurrenberger et al., 2001) (Fig. 2). The sedimentological analyses characterize the evolution of the depositional environment of the lake and, in combination with other geological and biological data, allow reconstruction of past climatic variability (Valero-Garcés et al., 2003) (Fig. 2).

Among the geological proxies, the main palaeoindicators used to identify and characterize the sedimentary processes controlling the input, transport and deposition of sedimentary particles, i.e. essential information for understanding the infilling of the lacustrine system are: (1) mineralogical composition, derived from X-ray diffraction analyses; (2) elemental geochemistry, obtained at highresolution by X-ray fluorescence (XRF) core scanning (Last, 2001) or as discrete samples by other methods (ICP, conventional XRF); (3) concentration of total organic (TOC) and inorganic (TIC) carbon, and (4) stable isotope composition $\left(\delta^{18} \mathrm{O}\right.$ and $\left.\delta^{13} \mathrm{C}\right)$ in carbonates or bulk organic matter (Fig. 2). The combined analysis of these proxies provides important information regarding, for example, the input and composition of detrital minerals versus the precipitation of endogenic components (Corella et al., in press), or data about the hydrological balance and temperature of lake water (Morellón et al., 2009a). Among the biological proxies used for palaeolimnological reconstructions, the most commonly employed are (1) pollen, (2) diatoms, (3) ostracods and/or (4) chironomids (e.g., Moreno et al., in press-b) (Fig. 2). These indicators provide information related to the type and extension of the vegetation cover (e.g., Carrión, 2002) and also environmental (temperature, precipitation) and limnological ( $\mathrm{pH}$, lake level, nutrients, water column mixing) conditions in the lake (e.g., Leira, 2005). The integrated multi-proxy approach in the study of lake sequences is critical for disentangling the different forcings influencing lacustrine systems, an indispensable pre-requisite for robust reconstructions of climatic variability.

The chronology in the selected records was mainly based on the AMS ${ }^{14} \mathrm{C}$ technique and the dates were calibrated for this review using the INTCAL09 calibration curve (Reimer et al., 2009) (see Supplementary Table S1). Additionally, other dating techniques were used, such as U-Th disintegration series in the carbonates from Banyoles record (Pérez-Obiol and Julià, 1994); Optically Stimulated Luminescence (OSL) in Villarquemado palaeolake (Valero-Garcés et al., 2007), and palaeomagnetism excursions in Fuentillejo maar (Vegas et al., in press). Final construction of the age models was carried out by linear interpolation between the obtained dates, except on Enol and Estanya lakes where a generalised mixed-effect regression was used, following Heegaard et al. (2005). Although the records selected for this review are characterized by robust chronological control, some general problems are nevertheless evident (e.g. calibration difficulties for the dates beyond 45,000 years in longer sequences such as Fuentillejo maar,

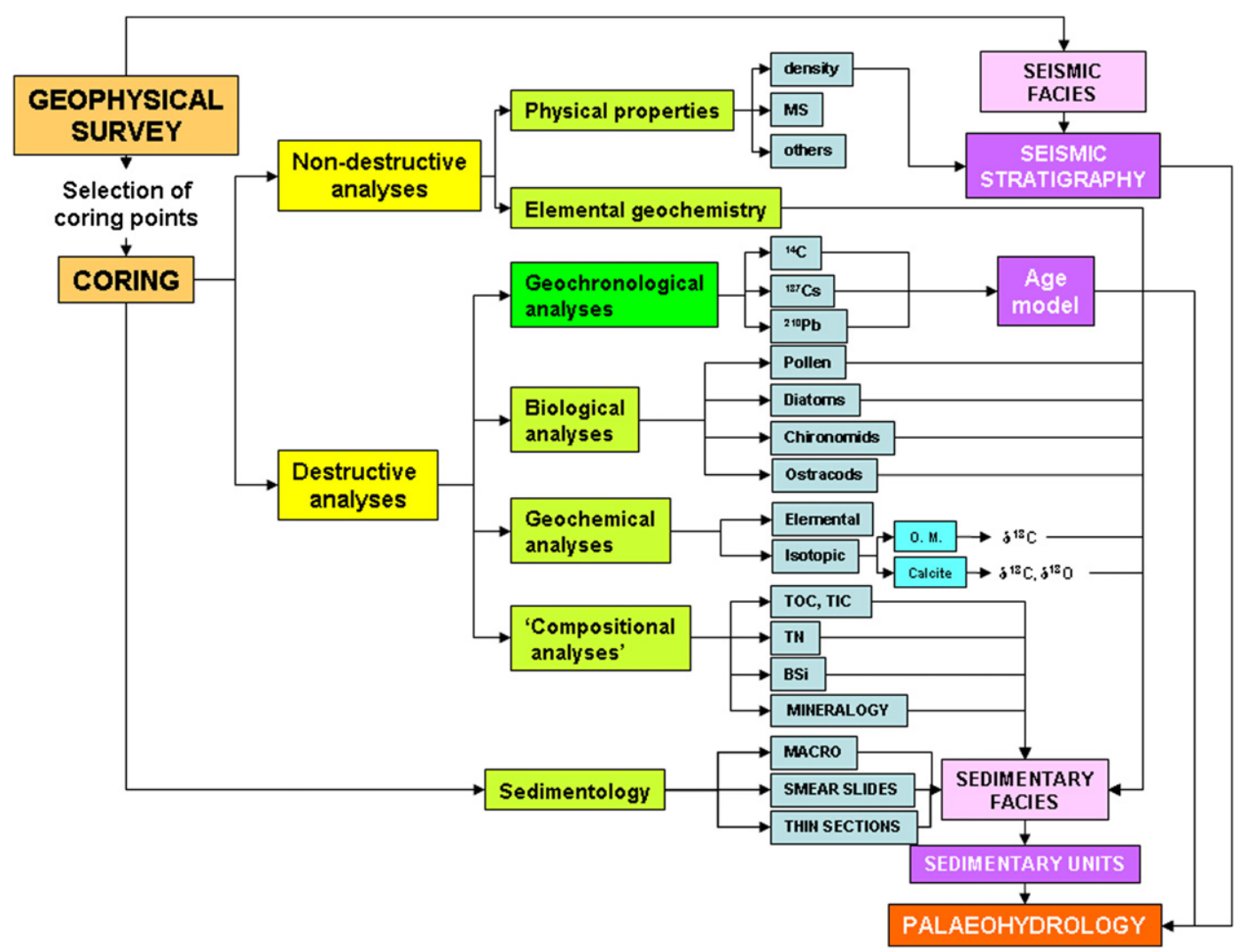

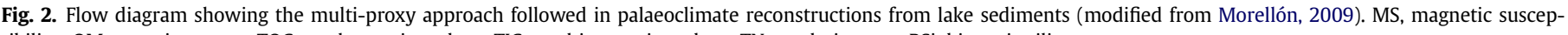
tibility; OM, organic matter; TOC, total organic carbon; TIC, total inorganic carbon; TN, total nitrogen; BSi, biogenic silica. 
scarcity of organic terrestrial remains in glacial lakes such as Enol Lake, etc.) that remain difficult to overcome. However, when necessary, these limitations are discussed in order to avoid misinterpretation of the main climate trends.

\section{The Iberian climate reconstruction during last glacial cycle}

Very few multi-proxy studies from lake records in the IP cover the time interval from last glacial inception (ca. $120 \mathrm{ka}$ ) to the "global LGM". ${ }^{1}$ In fact, from Table 1 we can only cite Fuentillejo maar (142.4 m) (Vegas et al., in press) and Villarquemado palaeolake $(74 \mathrm{~m}$ ) sequences, both obtained in present-day dry lakes using a truck-mounted drilling system. Several sequences cover MIS 3 and a larger number includes MIS 2 (Table 1).

\subsection{The beginning of last glacial cycle in Northern Iberia (MIS 5 and} MIS 4)

The Greenland NGRIP ice core offers an undisturbed record of the last glacial inception and reveals a rapid event, D/O 25, occurring about 115,000 yrs ago when the northern hemisphere ice volume reached about one third of its glacial extent (NGRIP Members, 2004). Mediterranean pollen data show that the interglacial forest environment is preserved during this period (mean percentage of temperate pollen around $40-50 \%$ ) but also responded to rapid $\mathrm{D} / \mathrm{O}$ events, indicating that the early glacial millennialscale variability in Greenland has an European counterpart (Tzedakis et al., 2003; Masson-Delmotte et al., 2005; Sánchez-Goñi et al., 2008). In the IP, the full details of the nature and timing of the onset of last glacial cycle and its possible correlation with other North Atlantic marine records and Greenland ice cores are not fully constrained. The most detailed available information comes from Iberian margin marine records, which yield information about palaeoceanographic conditions and, through pollen analysis and direct land-sea correlation, provide evidence of regional-scale vegetation changes during the last glacial inception (e.g., ODP977/ A: Martrat et al., 2004; Pérez-Folgado et al., 2004; ODP976: Combourieu Nebout et al., 2002; MD95-2042: Sánchez-Goñi et al., 1999, 2008; MD99-2331: Sánchez-Goñi et al., 2005; MD04-2845: Sánchez-Goñi et al., 2008). These studies indicate a $\sim 10^{\circ}$ southward displacement of vegetation belts in western Europe as early as $\sim 121 \mathrm{ka}$ as part of continental-scale vegetation changes which may have played a role in triggering the last glaciation (Sánchez-Goñi et al., 2005). Overall, an apparent synchrony with global climate events is shown, both in sea surface temperatures (Martrat et al., 2004) and pollen data (Sánchez-Goñi et al., 2008), reflecting millennial-scale climate variability associated with MIS 5 substages and $\mathrm{D} / \mathrm{O}$ events $25-19$, and following a long-term trend towards a cold and arid glacial scenario.

In the terrestrial realm, the lack of well-dated lacustrine sequences for this period prevents the detailed characterization of the beginning of last glacial period on land and the nature and impacts of rapid climate oscillations. As an example, the available chronology for the Fuentillejo maar record is not yet clear beyond the limits of the ${ }^{14} \mathrm{C}$ method, except for a magnetic reversal at the base that provides evidence of the Matuyama-Brunhes boundary

\footnotetext{
${ }^{1}$ We will use the term "global LGM", according to EPILOG (Environmental Processes of the Ice Age: Land, Oceans, Glaciers, http://www.glacialoceanatlas.org/ index.php?option $=$ com_content\&view $=$ artilcle $\& i d=55 \&$ itemid $=2$ ) project, for the period from 23,000 to 19,000 yrs BP that refers to the time of maximum extent of the ice sheets during the last glaciation - the Würm or Wisconsin glaciation (Mix et al., 2001). In Iberian Peninsula, the time of maximum glacier extension does not correspond to the global LGM.
}

(780 ka) (Vegas et al., in press) and extends the record to at least the beginning of the Middle Pleistocene.

The Villarquemado palaeolake sequence was dated by combining ${ }^{14} \mathrm{C}$ (for the uppermost $20 \mathrm{~m}$ ) and OSL (for the remaining $52 \mathrm{~m}$ ) techniques, yielding a basal age of ca. $120 \mathrm{ka}$, thus covering the period from MIS 5 to present-day (Fig. 3). This record lacks an adequate time control for the interval between $20-48 \mathrm{~m}$ (corresponding to $\sim 41.5 \mathrm{ka}-72.5 \mathrm{ka}$ ). Thus, boundaries between MIS5-MIS4 and MIS4-MIS3 were placed in Fig. 3 on the basis of sedimentary unit boundaries. The Villarquemado sequence is composed of peatbog, alluvial fan and carbonate lake deposits and the basin was likely a variable mosaic of these three depositional environments during its evolution. In this sense, development of a carbonate lake (with high contents of Ca and TIC and lower MS values) represents higher lake levels than a peatbog setting (higher TOC, lower MS) while alluvial fan deposits (lower carbonate and TOC content, higher MS) represent the lowest lake levels in the basin. Thus, in the Villarquemado sequence, TOC values are higher during the Holocene (Unit I, 0-3 m) and MIS 5 (Units VI and VII, 37-74 m) (Fig. 3) with the most significant development of wetlands of the whole sequence, characterized by the alternation of peatbog and shallow carbonate lake environments. A significant depositional change in the basin is recorded at the onset of MIS 4, with the retreat of the wetlands and the progradation of the distal alluvial fans indicative of a tendency towards lower lake levels (Unit V, 29-37 m, Fig. 3).

Other Iberian records based on pollen data also show large changes at the onset of the last glacial cycle. In the NW IP, the Area Longa sequence, recovered from a beach cliff, spans the interval from MIS 5c to MIS 3 (Gómez-Orellana et al., 2007) (Fig. 1). The base of this pollen record (ascribed to MIS $5 c$, corresponding to St. Germain I phase) is dominated by deciduous woodland (Alnus, Quercus robur type, Corylus, Betula and Carpinus) with high proportions of Fagus. During MIS 4, high percentages of Erica, Calluna and Poaceae indicate heath and temperate grassland as the predominant vegetation types with a low abundance of conifers and persistence of meso-thermophytes such us Quercus robur type, Corylus, Fagus, Carpinus, Ulmus and Ilex. The authors' interpretion is that while the NW IP was affected by cooling that occurred globally during MIS 4, its climate continued to be relatively humid, mostly based on the high Ericaceae and Poaceae percentages and the low steppe taxa values (Artemisia, Chenopodiaceae) that dominate the herbaceous component. In NE Spain, the Abric Romaní travertine rock shelter provides palaeobotanical information for the interval 70,000-40,000 years BP (Burjachs and Julià, 1994) (Fig. 1). Tree pollen percentages in the oldest deposits (attributed to MIS 5a) reach $40-60 \%$, dominated by pines but with a continuous presence of Juniperus, Rhamnus, Quercus, Olea-Phillyrea, Betula, Fagus, Pistacia and other mesothermophilous taxa. The transition to MIS 4 represents a cold but humid phase with less thermophilous taxa (Burjachs and Julià, 1994).

Therefore, up to now and until more data from Villarquemado palaeolake are available, we can summarize from the scarce available terrestrial records covering MIS 5 to MIS 4 that a consistent climatic change was observed across the IP in terms of temperature, with cooling after ca. 65,000 cal years BP. In contrast, patterns of moisture availability appear more variable, as detected from marine pollen data. Thus, records from the northern and northwestern margins of the IP indicate cool, humid conditions promoting the development of Ericaceae and conifers during MIS 4 (e.g., MD04-2845 and MD99-2331 marine cores: Sánchez-Goñi et al., 2005, 2008, respectively), while records from the southern margins indicate drier conditions, with greater development of semi-desert vegetation (e.g., MD95-2042 and ODP site 976, reviewed in Fletcher et al., 2010). At all sites, however, a trend of 


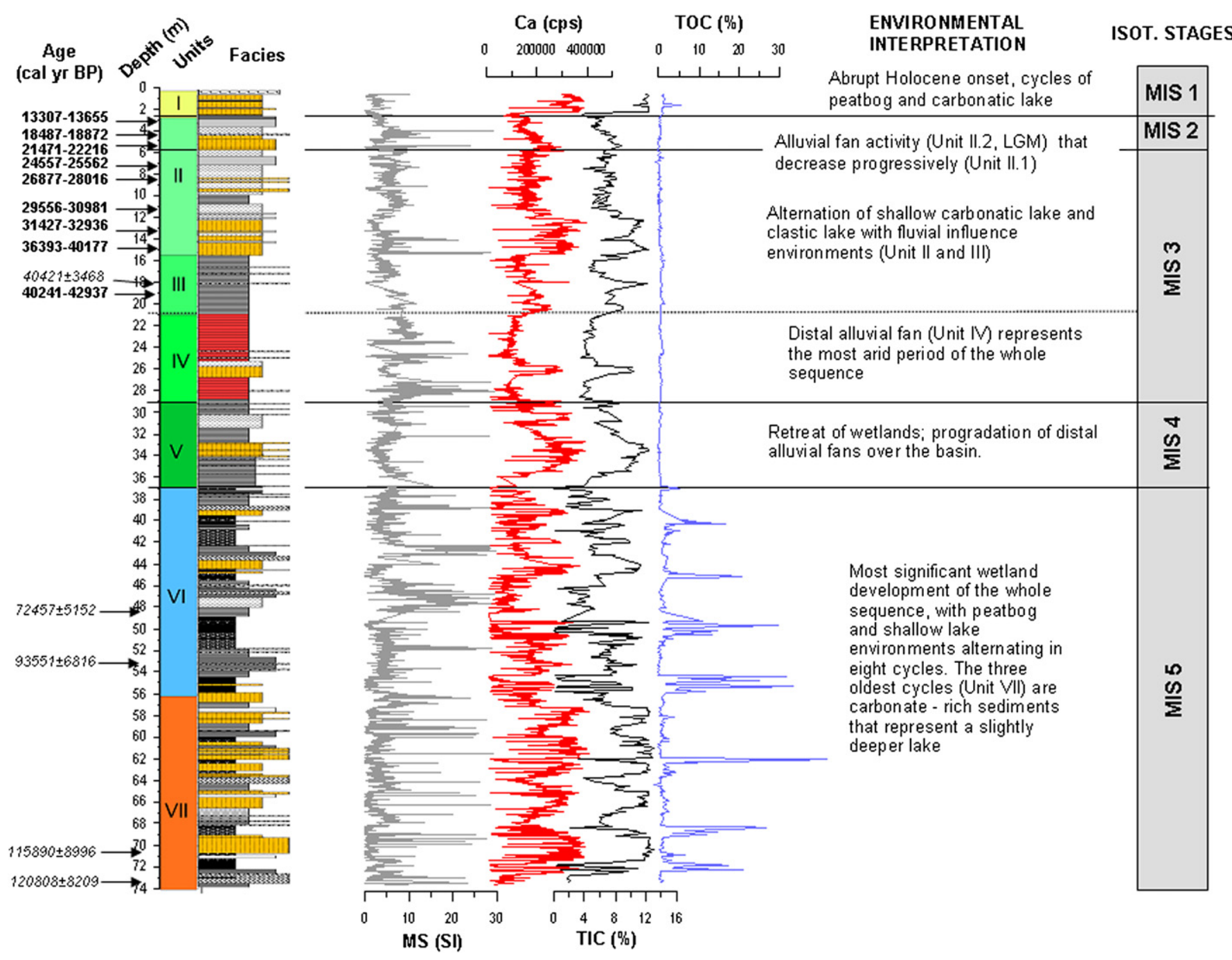

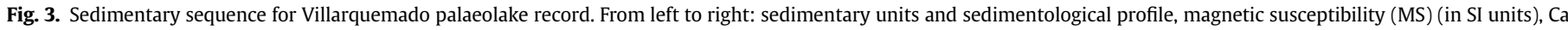

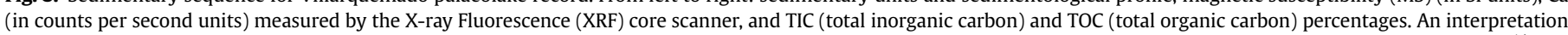

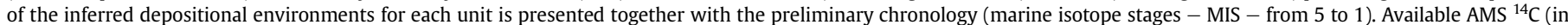
bold type) and -OSL dates (in italics) are shown to the left.

gradually increasing aridity over the MIS 4 interval is apparent (Sánchez-Goñi et al., 2008; Fletcher et al., 2010).

Glacier records from the Central Pyrenees (García-Ruíz et al., 2003; Pallàs et al., 2006; Lewis et al., 2009) provide coherent support for the prevalence of relatively humid conditions at the transition between MIS 5 and MIS 4 in northern IP. Thus, the most external moraines in the Spanish Central Pyrenees are dated by OSL at $85 \pm 5 \mathrm{ka}$ (Peña et al., 2003; Lewis et al., 2009), placing the timing of the "Iberian last glacial maximum" close to the transition between MIS 5 and MIS 4 (García-Ruíz et al., 2010). This scenario of cold temperatures, significant humidity across the northern IP, and a gradual decline in humidity across MIS 4, may partly underline why the timing of maximum extent of other Mediterranean glaciers is much earlier than the global LGM (see a review in Hughes and Woodward, 2008). Besides the asynchrony in the maximum ice extent, there is also a discrepancy in the timing of last deglaciation, which appears to have occurred earlier in the Pyrenees (García-Ruíz et al., 2003; Pallàs et al., 2006; Lewis et al., 2009) and the Cantabrian mountains (Jiménez Sánchez and Farias, 2002) than in other European mountains. An explanation for this early glacier retreat may be found in the abrupt climate changes that occurred later, during MIS 3.

\subsection{The record of rapid climate cycles in lake sediments (MIS 3)}

Since the study carried out by Lebreiro et al. (1996), where the first evidence of Heinrich layers was found in marine sediments offshore Portugal, many other records, mostly from marine cores, have highlighted abrupt fluctuations in the Iberian climate during MIS 3 synchronous with HE and D/O cycles (e.g. Cacho et al., 1999; Frigola et al., 2008). From the palynological study on marine cores, it is now accepted that those fluctuations also produced important changes on land, mostly via changes in water availability and temperature that could have a great impact on vegetation cover (Sánchez-Goñi et al., 2000, 2002, 2008; Roucoux et al., 2001, 2005; Combourieu Nebout et al., 2002, 2009; Fletcher and Sánchez-Goñi, 2008; Naughton et al., 2009; Fletcher et al., 2010). In addition, other terrestrial tracers measured on marine sediments, such as indicators of fluvial and aeolian activity (Moreno et al., 2002, 2005; BoutRoumazeilles et al., 2007; Frigola et al., 2008), also point to millennial-scale D/O fluctuations in IP aridity (Fig 4). Recent highresolution studies detected a two-phase hydrological pattern for some HE in a marine core offshore Galicia (Naughton et al., 2007) which has been subsequently confirmed by a speleothem record from northern Iberia (Moreno et al., 2010). 
In contrast to the relatively high number of marine records covering this time interval, lake sequences from the IP covering MIS 3 and demonstrating a response on land to rapid climate oscillations are scarce. In fact, even considering lacustrine records at a European scale, the lake sequences where $\mathrm{D} / \mathrm{O}$ cycles have been clearly observed and dated are limited (e.g., Allen et al., 1999; Wohlfarth et al., 2008). Considering that lakes are very sensitive ecosystems to small environmental changes, why are MIS 3 climate fluctuations not more clearly recorded? The most plausible explanation is that sampling resolution has generally not been high enough, limited in some cases by low glacial sedimentation rates and compounded by the difficulties of constructing accurate chronologies for this time period (i.e., the ${ }^{14} \mathrm{C}$ method is close to its maximum limit and, additionally, lake sediments, particularly from proglacial lakes, are characterized by low organic content during this interval thus restricting even more the dating potential (Moreno et al., in press-a)). Although laminated records from karstic lakes will probably provide better candidates (with more robust chronologies supported by counting annual laminae and higher sedimentation rates permitting the detection of abrupt changes), there is no record in the IP studied up to now with such features.

In the Villarquemado palaeolake, the aridity trend that started during MIS 4 continued and peaked during the lower part of MIS 3

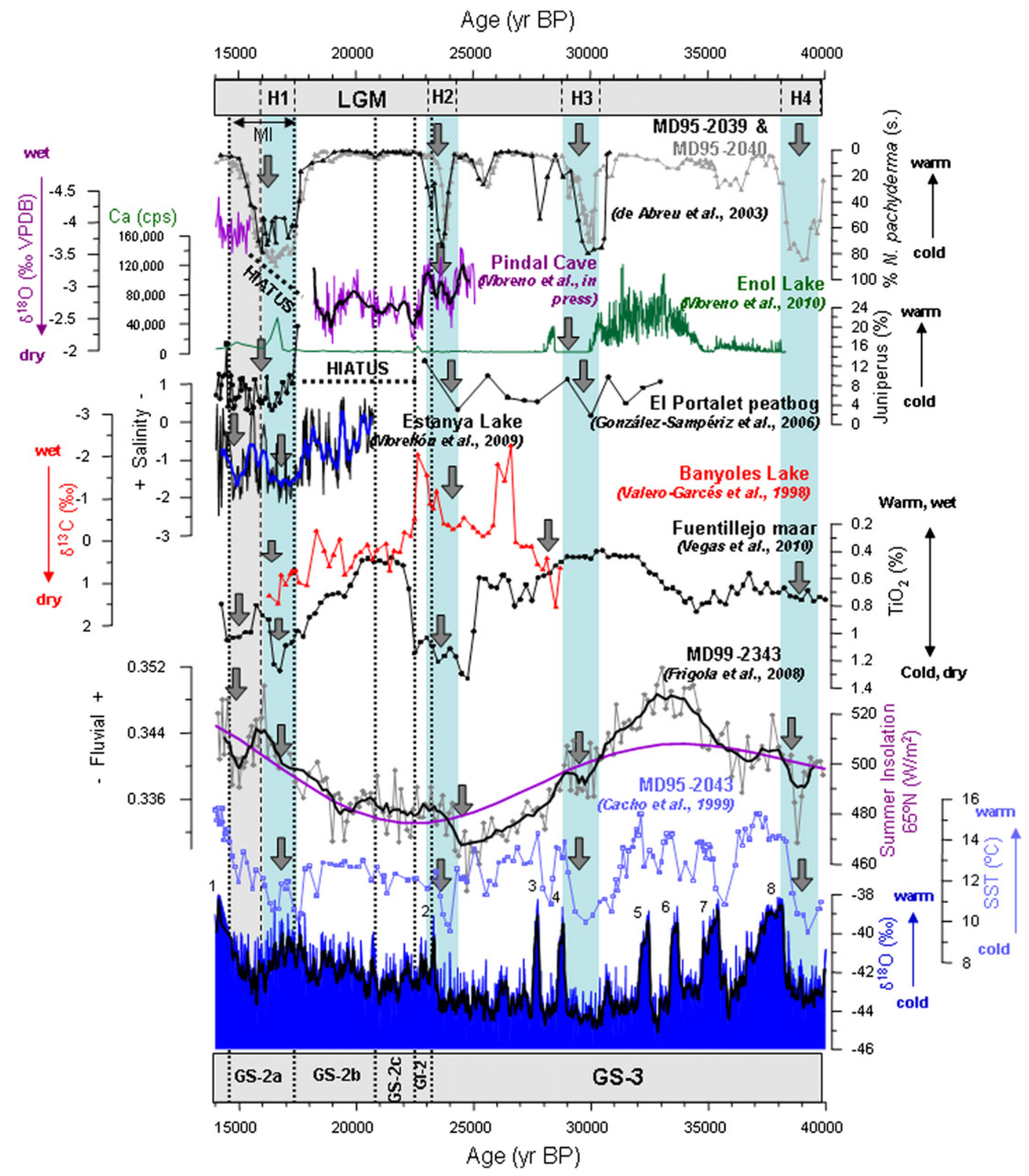

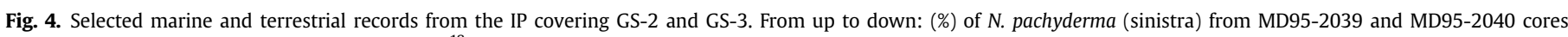

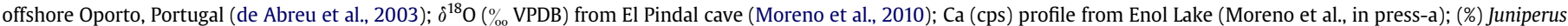

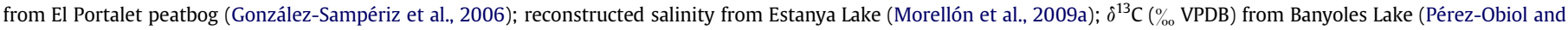

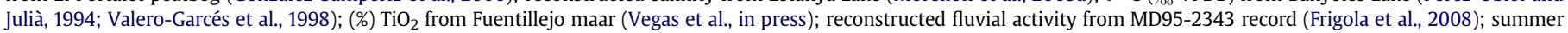

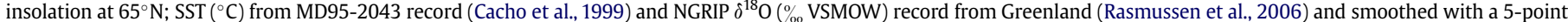

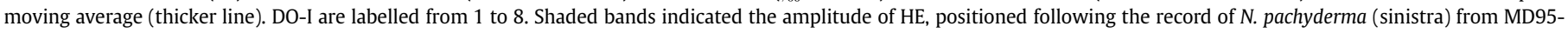
2039 and MD95-2040 cores (de Abreu et al., 2003). 
(Unit IV, 21-29 m; Fig. 3) where sedimentological evidence for ephemeral lake conditions (dolomite formation, red, oxidized fine sediments) is present. After around 40,000 cal yrs BP, an alternation of shallow carbonate lake deposits and distal clastic alluvial fan materials reflect rapid hydrological and climate fluctuations during MIS 3, although the ascription to individual events is still not possible with the available chronological model. More dates throughout the MIS3 interval and the palynological study of the whole sequence, currently in progress, will aid the detection of MIS 3 variability. Although dating uncertainties are high in the Fuentillejo maar record from central IP (Table 1, Fig. 1) due to linear interpolation between very few dates $\left(6\right.$ AMS ${ }^{14} \mathrm{C}$ dates for the last 50,000 years), several fluctuations ascribed to HE and other stadials of the $\mathrm{D} / \mathrm{O}$ cycles have been identified and interpreted as arid periods (Vegas et al., in press). Based on the combination of several proxies (sedimentology, geochemistry, pollen, etc.), HE5 and HE3 have been identified as relatively warm periods while $\mathrm{HE} 4,2$ and 1 were significantly colder $\left(\mathrm{TiO}_{2}\right.$ percentage is plotted in Fig. 4 as a proxy for dry/cold conditions). The authors refer to regional processes as the cause of modifications in the intensity and persistence of these rapid climate oscillations (Vegas et al., in press).

The site that provided initial clues about MIS 3 climate fluctuations in the IP is the Banyoles pollen record, first published by Pérez-Obiol and Julià (1994). A later study of sedimentary facies and stable isotopes on charophytes from the same littoral core reveals impacts on the sediments of HE 3 and 2 that are interpreted as dry periods characterized by lower lake levels (Valero-Garcés et al., 1998) (Fig. 4). Besides Banyoles, other locations in the northern IP, notably El Portalet peatbog and Enol Lake (Table 1, Fig. 1), responded to the arid and cold conditions of HE3 and HE2 (González-Sampériz et al., 2006; Moreno et al., in press-a) (Fig. 4). Particularly clear is the record of El Portalet peatbog where an increase in steppe taxa and a decrease in Juniperus frequencies, together with a more abundant siliciclastic component in the sediments, occurred during cold and arid phases associated with rapid events of climate change (González-Sampériz et al., 2006).

Dating the base of sedimentary sequences obtained from proglacial lakes or glaciolacustrine deposits has provided useful information for reconstructing the deglaciation stages in the Spanish mountains during MIS 3 (González-Sampériz et al., 2005). There are four noteworthy proglacial lake records that support an early deglaciation: (1) a basal age of 32.5 ka from El Portalet peatbog at $1802 \mathrm{~m}$ a.s.l. (González-Sampériz et al., 2006); (2) a basal age of around $33.9 \mathrm{ka}$ from Tramacastilla glacial lake at $1640 \mathrm{~m}$ a.s.l. (García-Ruíz et al., 2003; Pallàs et al., 2006; Lewis et al., 2009), both located in the Pyrenees; (3) a basal age of 38 ka from Lago Enol in the Cantabrian Mountains at $1075 \mathrm{~m}$ a.s.l. (Farias-Arquer et al., 1996; Moreno et al., in press-a); and (4) a basal age of $25.5 \mathrm{ka}$ from Lago de Sanabria in NW Spain at $997 \mathrm{~m}$ a.s.l (Rico et al., 2007). All these ages postdate glacier activity in the area and, since the lakes are located at or close to the headwaters of the different basins, and behind terminal moraines, it means that the glaciers had already retreated to their cirques or very close to them by 40-30 ka.

Although several hypotheses have been postulated, up to now a satisfactory explanation for the early glacier retreat has not yet been found (Gillespie and Molnar, 1995). However, it seems clear that it was related to the high sensitivity of Mediterranean mountain glaciers to climate changes resulting from their distinctive characteristics such as their geographical location and their smaller size (Hughes and Woodward, 2008). Recently, García-Ruíz et al. (2010) have proposed that the sustained increase of the Scandinavian inlandsis between 80 and 55 ka BP (Svendsen et al., 2004) had parallels in the Mediterranean mountains, with rapid glacier growth that lead to maximum ice extension of some of the glacier tongues approximately at the transition from MIS 5 to MIS 4. Later on, during MIS 3, and due to the well-known abrupt climate fluctuations associated with the $\mathrm{D} / \mathrm{O}$ cycles, the Scandinavian inlandsis may have stabilized thanks to its larger inertia, but the Mediterranean glaciers may have experienced a noticeable retreat during warm events. It is interesting to note that the Villarquemado record also points to more humid conditions during MIS 4 and MIS 2 than during MIS 3 (Fig. 3), coherent with higher long-term moisture availability in the IP as a pre-requisite for glacier advances.

More records from lakes and glacier evolution and an increased effort on dating, possibly combining dating techniques $\left({ }^{14} \mathrm{C}, \mathrm{OSL}\right)$, are necessary to go further in the identification of the effects on land of rapid climate changes during MIS 3.

\subsection{From the global LGM to the Holocene onset (MIS 2/GS-2)}

The global LGM can be defined as the most recent interval when global ice sheets reached their maximum integrated volume during the last glaciation (Mix et al., 2001). However, as we noted above, the glacier advance associated with the global LGM may be of smaller magnitude for Mediterranean, and particularly Iberian glaciers, than that which occurred during MIS 4 (García-Ruíz et al., 2010). The period since the global LGM to the Holocene onset (GS-2, GI-1 and GS-1 in the INTIMATE nomenclature; Lowe et al., 2008) is well-represented in many marine records surrounding the IP (e.g., Cacho et al., 2001; Jiménez-Espejo et al., 2007; Naughton et al., 2007; Combourieu Nebout et al., 2009; Fletcher et al., 2010), and it appears as a period with high variability, including events of abrupt climate change such as HE2 and HE1 and rapid climate fluctuations during LGIT (GI-1, GS-1). Additionally, many Iberian lake records (see Table 1, Figs. 4 and 5) cover this time interval and can provide some answers to questions about the nature, timing, regional particularities and spatial variability of the main climate changes in the IP since global LGM.

\subsubsection{Was the global LGM the coldest and driest interval of MIS 2 in the IP?}

One of the most important questions to be addressed in relation to climate variability in the IP is the signal on land of the global LGM (GS-2b). Although it is now evident that the global LGM does not correspond in most Iberian mountains to the maximum glacier extension (Lewis et al., 2009), was that period the coldest interval of the last ca. 25,000 years? Was it relatively wet or dry? Marine records from Iberian margins indicate that the global LGM, although undoubtedly cold, was not the coldest interval in the marine realm (e.g., Alboran Sea, Cacho et al., 1999; Portuguese margin, de Abreu et al., 2003) (Fig. 4). In contrast, HE1 (dated about 16,000 years BP) is generally marked by the highest percentages of cold foraminifer Neogloboquadrina pachyderma (s), the highest values of IRD, or the lowest SST reconstructed for the last 23,000 years. In terms of hydrological changes, HE1 appears also drier than global LGM in offshore Menorca record (based on the K/Al ratio as indicator of fluvial activity in Frigola et al., 2008, see Fig. 4) and in many marine pollen records (Beaudouin et al., 2007; Naughton et al., 2007; Combourieu Nebout et al., 2009; Fletcher et al., 2010). Model simulations obtained a clear reduction in both temperature of the coldest month and in precipitation for the HE1 interval respect to global LGM in Iberia and highlighted a more significant response on the European Atlantic coast that decreases very rapidly inland (Kageyama et al., 2005). Data from continental sequences in the IP, related to temperature and water availability comparing global LGM and HE1, are available to corroborate or reject those model outputs. 


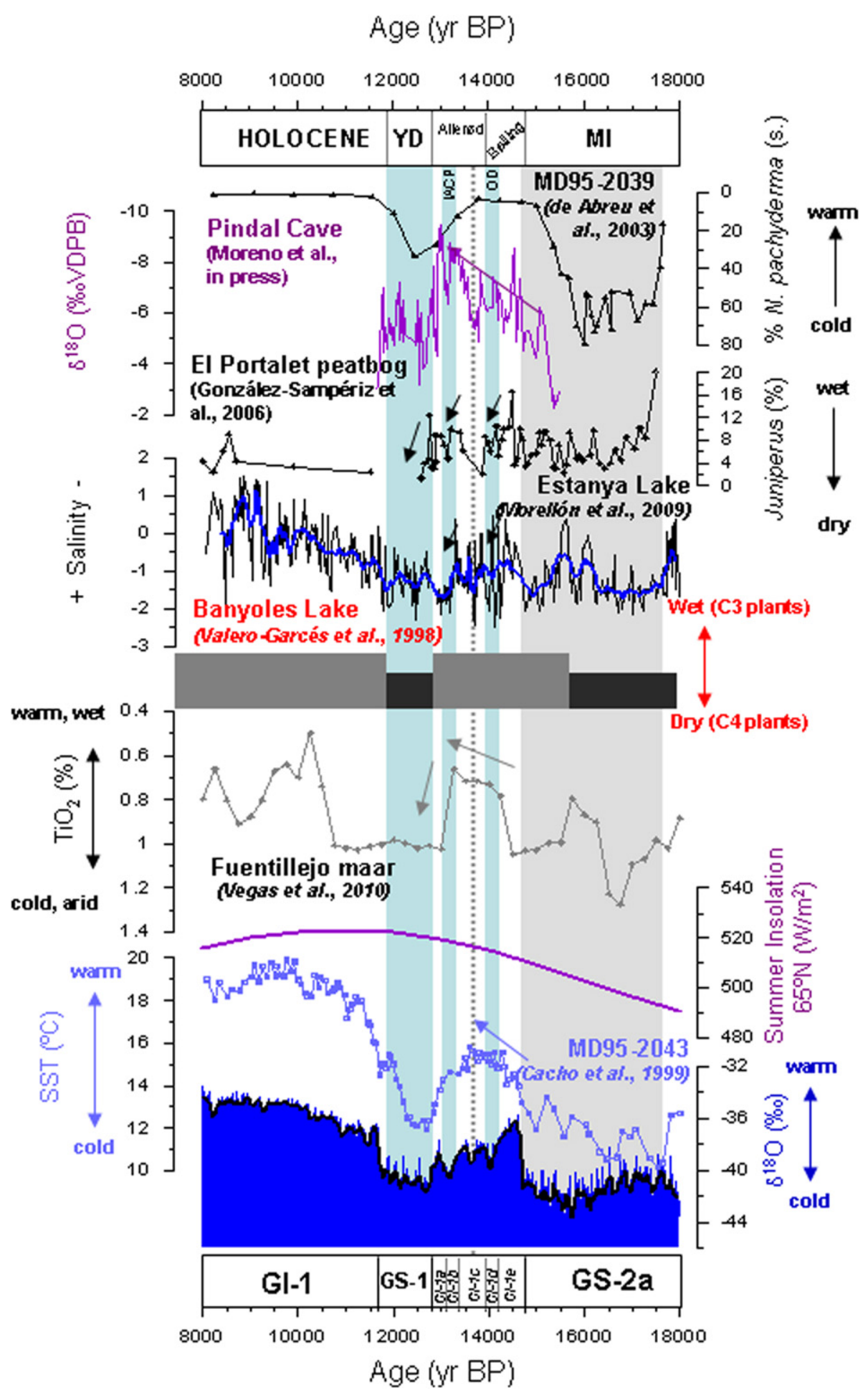

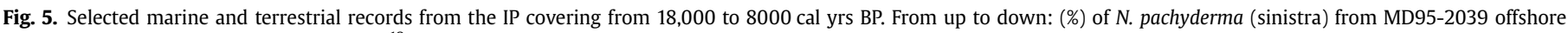

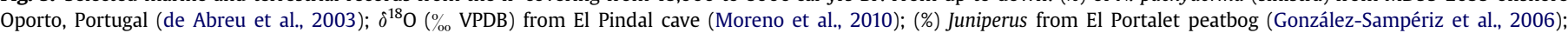

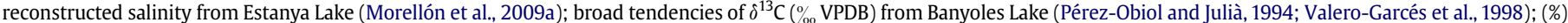

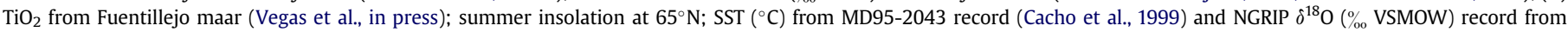

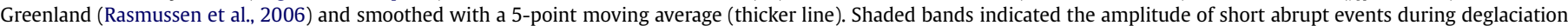
and arrows mark tendencies (see text for discussion).

In general, recently studied lake sequences from the IP support previous interpretations from marine sediments, and in particular are in agreement with the relatively humid hydrological signal of global LGM. In Villarquemado palaeolake (Figs. 1 and 3), MIS 2 is characterized by a decrease in alluvial fan activity and more development of carbonate lake environments than before, pointing to relatively humid conditions during the LGM. In Estanya Lake (Fig. 1, Morellón et al., 2009b), a shallow carbonate-producing lake system during the global LGM (from the onset of the lake sequence, ca. 21,000-18,000 cal yrs BP), contrasts with a closed, permanent 
saline lake characterized by an evaporitic dominant sedimentation (starting at 18,000 and lasting until 14,000 cal yrs BP) (Fig. 4). Therefore, the global LGM was not the driest interval in the PrePyrenees and the significant reduction in runoff occurred afterwards (Morellón et al., 2009a). Additionally, the preservation of lacustrine sediments in several records from playa-lakes in the Central Ebro Basin during the global LGM (see summary in Gonzalez-Samperiz et al., 2008), suggests phases of increased moisture during this period. Thus, the global LGM was probably characterized by periods of positive hydrological balance perhaps caused by reduced summer insolation at the latitude of Iberia (Fig. 4). If that was the case, evapotranspiration during the summer months may have decreased, contributing to relatively high lake levels without a significant increase in rainfall, as suggested by the reconstruction provided by the Estanya Lake record (Morellón et al., 2009a). An additional factor with the potential to increase water availability in certain areas is the expected high fluvial discharge produced in relation to the deglaciation process in the mountains (Valero-Garcés et al., 2004; González-Sampériz et al., 2005) which had already started by this time. There is some evidence of that process in the form of flood deposits in global LGM terraces indicative of a period of high discharge (Sancho-Marcén et al., 2003) that correlates with an increase in fluvial activity just after global LGM (Frigola et al., 2008).

Although temperatures are usually more difficult to reconstruct from lake sediments than hydrological balance (Cohen, 2003), pollen data from lacustrine sequences provide clear evidence for the IP of a cold scenario for the global LGM until the beginning of the Bølling/Allerød (see compilation in González-Sampériz et al., in press): the landscape was dominated by cold steppe formations with a minor presence of conifers and restricted occurrence of meso-thermophytes. In sequences with higher sample and temporal resolution, detailed interpretation of pollen spectra provides evidence for a particularly cold interval associated with HE1. Thus, in El Portalet peatbog, HE1 is detected by the presence of gray siliciclastic silts indicating low lake productivity, a decrease in Juniperus and increase of steppe taxa (González-Sampériz et al., 2006). Similarly, more positive values of $\delta^{13} \mathrm{C}$ in carbonates were found in Banyoles record (Pérez-Obiol and Julià, 1994; ValeroGarcés et al., 1998) (Fig. 4).

From all the recent evidence outlined above, we can conclude that the most arid and coldest period in the IP during GS-2 occurred in within the GS-2a (Fig. 4). This interval has been called the "Mystery Interval" (MI) (Denton et al., 2005), and embraces the marine HE1 thus corresponding to the first phase of last glacial termination (17.5-14.5 cal kyr BP). In the Enol Lake record, the MI corresponds to the lowest linear sedimentation rate of the whole sequence pointing to very low runoff and thus little transport to the lake (Moreno et al., in press-a). In addition, the MI coincides with a hiatus in the formation of a speleothem from El Pindal Cave, in northern Spain, also suggesting a dry (and cold) period (Moreno et al., 2010). The same stalagmite grew during the global LGM, pointing to less extreme climate conditions at that time compared to the MI (Fig. 4). However, up to now, the evidence from lakes (or speleothems) has not been sufficiently accurate to discriminate chronologically whether the arid period includes the whole MI interval (ca. GS-2a) or whether it is more constrained to HE1, as seems to be the case from marine temperature records (Cacho et al., 2001). In fact, some sequences record two pulses during the MI (e.g., Estanya Lake salinity reconstruction or Fuentillejo maar $\mathrm{TIO}_{2}$ aridity indicator) while others (e.g., Juniperus percentages in El Portalet peatbog) only point to one longer cold/dry event embracing the whole GS-2a interval (Fig. 4).

Despite chronological uncertainties and the different responses suggested by the available lake records (i.e. one or two pulses), the important effect of the Meridional Overturning Circulation (MOC) on the IP climate and the rapid response of terrestrial ecosystems to MOC variability is evident. The MI marks the start of the first phase of the last glacial termination (T1a) and was characterized by the strong reduction of MOC (McManus et al., 2004) in comparison to LGM levels due to high rates of freshwater input during iceberg discharges of HE1. The shutdown in MOC lasted $2000 \mathrm{yr}$ and caused extremely cold winter temperatures in the North Atlantic area (Denton et al., 2005) and likely formed sea ice, reduced sea surface evaporation and consequently produced dry conditions in Europe (Wohlfarth et al., 2008) and into Asia (Cheng et al., 2006). Therefore, as a consequence of the close connection between western European temperatures and MOC intensity, IP temperatures are colder during the MI than during the earlier global LGM period.

\subsubsection{When and how did the last deglaciation occur in the IP?}

Terminology for the last deglaciation was first defined from the Fennoscandian region based on pollen sequences and the corresponding vegetation changes, including periods such as the Bølling-Allerød or the Younger Dryas (Mangerud et al., 1974), that correspond in the INTIMATE nomenclature referring to Greenland ice records to GI-1 and GS-1, respectively (Björck et al., 1998) (Fig. 5). The last deglaciation was characterized by a series of abrupt climatic changes (GI-1a-GI-1e, GS-1), with broadly similar trends identified in palaeoclimate records obtained from many sites throughout the North Atlantic region. However, the extent to which the North Atlantic sequence of climatic changes is reflected in palaeoclimatic records from the IP, in terms of timing and pattern of the abrupt climatic changes, is still a matter of debate (e.g., Carrión et al., in press). From marine cores surrounding the IP, at least two particularities with respect to Greenland records have arisen: (1) the earliest onset of warming associated with the first phase of the last deglaciation occurred at $\sim 15.5 \mathrm{cal}$ kyr BP, prior to further and more marked warming at the onset of the GI-1 (Fletcher et al., 2010), and (2) a stable - to warming trend in sea surface temperatures during GI-1 is observed in contrast to the cooling trend recorded in Greenland (Cacho et al., 2001). Furthermore, recent analyses of pollen records in southern Iberian marine cores indicate short-lived intervals of forest decline consistent with cooling and drying during the GI-1d (Older Dryas) and GI-1b (Inter-Allerød Cold Period) (Combourieu Nebout et al., 2009; Fletcher et al., 2010). The lack of accurate chronologies and high-resolution analyses in continental records has precluded the identification of abrupt climate changes within GI-1 until recently (e.g., González-Sampériz et al., 2006). New lake sequences like Villarquemado palaeolake, combining the study of vegetation and the response of the lake system itself to climate changes, will provide key information for the characterization of abrupt changes experienced during last deglaciation.

In the northeastern IP, the hydrological response to abrupt climate change during the last deglaciation has been described in Estanya Lake (Fig. 1). In this record, the onset of GI-1 is detected by changes in sedimentation in the lake and a significant negative excursion of $\delta^{13}$ Corg values reflecting an increase in organic productivity likely related to deeper lake level conditions (Morellón et al., 2009a). The salinity reconstruction also points to a more positive hydrological balance during GI-1 and shows minor changes in response to short abrupt cold events, such as GI-1d and GI-1b, pointing to slightly drier conditions (Fig. 5). Similarly, the montane peatbog record from El Portalet reflects a decline in herbaceous steppe association, typical of glacial conditions, and an expansion of pioneer deciduous trees at the beginning of GI-1. Vegetation cover and sediment composition also reacted rapidly to shorter cold events with the deposition of siliciclastic silts and an increase in steppe plants and a decrease in Juniperus (GonzálezSampériz et al., 2006) (Fig. 5). 
In Laguna Grande and Laguna del Hornillo, both located in the western Iberian Range, the sequence of events within GI-1 have been identified by characterizing the laminations and the type and content of organic matter (Vegas, 2006). In these two lakes, an arid and cold event (GI-1d) is found between GI-1a (Allerød) and GI-1e (Bølling) but there is no signal around GI-1b, probably due to the low temporal resolution of the record. In other lakes from the wider Mediterranean region, a similar hydrological response to GI-1d and GI-1b events is observed (e.g., Lago dell'Accesa in Central Italy; Magny et al., 2006). On the contrary, an opposed palaeohydrological pattern is observed in central-western Europe, where G1-1d and GI-1b are characterized by higher lake levels in the Swiss Plateau, Jura mountains and French Pre-Alps (Magny, 2001). This latitudinal division in the hydrological response during abrupt climate changes occurring throughout last deglaciation, has been recently explained by the prevalence of "blocking episodes" that will favor or prevent cyclone penetration into the Mediterranean or northern and central Europe (Fletcher et al., 2010).

In the available lake records (Fig. 5), the onset of the warming trend associated with the Bølling period is synchronous, within age model uncertainties, with the onset of GI-1 in Greenland, but the pattern observed is more gradual than abrupt. Additionally, in Estanya Lake record, the Allerød period appears wetter than the Bølling period, in a similar way to that recorded in El Pindal cave located in northwestern Spain (Moreno et al., 2010) (Fig. 5). Similarly, the El Portalet pollen record reflects a generally reduced presence of steppe taxa and the first development, as opposed to occasional presence, of Corylus during the Allerød in contrast to the Bølling (González-Sampériz et al., 2006). Therefore, this pattern is consistent with Mediterranean marine SST records (Cacho et al., 2001) and differs from Greenland ice record where warmer temperatures over Greenland were reached abruptly at the onset of the Bølling period and declined afterwards (Fig. 5). The similar response of some lake (González-Sampériz et al., 2006; Morellón et al., 2009a) and speleothem (Moreno et al., 2010) sequences from northern IP and Mediterranean marine SST records (Cacho et al., 2001) to the global warming related to the first phase of the last glacial termination 1 (T1a), reflects a particular reaction in terms of temperature and water availability of this southern European region. This pattern may relate to a continental-scale $\mathrm{N}-\mathrm{S}$ latitudinal pattern of changing climatic evolution over the GI-1 interval as proposed by Genty et al. (2006), which should be better characterized for the IP with future studies.

\subsubsection{Timing, synchrony and ecosystems response to the Younger Dryas and the Holocene onset}

The second phase of last glacial termination (T1b) corresponds to the second weakening of the MOC during the Younger Dryas cold period, probably also triggered by a discharge of glacial meltwater (Hughen et al., 2000; McManus et al., 2004). While a clear response during the GS-1 interval (or Younger Dryas, YD) is detected in marine environments of the Iberian margin, mostly in terms of reduced sea surface temperatures (e.g. Cacho et al., 2001), clear response is less evident in continental archives from the Iberian Peninsula where a variable vegetation response is observed depending on the altitude and latitude of the studied records (Carrión et al., in press). Thus, changes in the landscape and vegetation cover during the YD appear to be more marked in mountainous areas (e.g., El Portalet peatbog record indicates that the lake was frozen all-year round, González-Sampériz et al., 2006) than in mid-to-low altitude sites (e.g., Lake Banyoles; Pérez-Obiol and Julià, 1994).

Other indicators measured in lake sequences besides vegetation are plotted in Fig. 5 and their combination supports the existence of a YD event in the northern IP as a dry and cold period without clear geographical variability. Thus, a lake level drop and salinity increase in Estanya Lake were indicated by the return to deposition of gypsum-rich facies and an abrupt decrease in organic productivity (marked by positive excursion of $\delta^{13}$ Corg and a sharp decrease in Bio Si) (Morellón et al., 2009a). In Banyoles Lake, the isotopic composition of authigenic carbonates $\left(\delta^{18} \mathrm{O}\right.$ and $\left.\delta^{13} \mathrm{C}\right)$ reaches peak values at around 12,000 years (Valero-Garcés et al., 1998) while sedimentation in El Portalet decreased dramatically or even ceased during the GS-1 in response to the previously mentioned permanent freezing of the lake (González-Sampériz et al., 2006). In Enol Lake, gray siliciclastic silts with low organic content and pollen spectra dominated by herbaceous taxa characterize an open landscape with scarce vegetation during the GS-1 unit (Moreno et al., in press-b). Similarly, the presence of massive clayey silts with low organic content in the Fuentillejo maar record (Vegas et al., in press), and significant changes in sediment stratigraphy and diatoms association in the Laguna Grande at Sierra de Neila (Vegas et al., 2003), indicate a cold and arid climate associated with the GS1 interval.

Thus, considering high and low altitude sites, the response to GS-1 in the IP lake records seems identical (Fig. 5). This finding may indicate that the different signals to the same climatic event recorded in the pollen spectra from different IP regions was linked to the distance to vegetation refuges that controlled the timing and intensity of the vegetation response. In addition, since most of the cases that are considered to show an "unexpected" response to GS1 lie in the Mediterranean-influenced climate region (Fig. 1), a centennial to millennial-scale resilience of the established forests can be presented as another explanation to account for the different vegetation responses (Gil-Romera et al., 2010; Carrión et al., in press). This view, however, is not in agreement with the findings of palynological research on Mediterranean marine cores, which suggest a rapid response of the Mediterranean forest cover to centennial-scale variability, both at the abrupt onset of the YD and within the GS-1 interval (Combourieu Nebout et al., 2009; Fletcher et al., 2010).

The onset of the Holocene represents an abrupt climate change towards warmer and, in general, wetter climates at 11,600 cal yrs BP (e.g., Hoek et al., 2008). Although this transition was apparently synchronous in different records from the IP, optimum Holocene climate conditions were not reached at the same time (Morellón et al., 2009a). In Estanya Lake, sedimentary and geochemical proxies indicate that the lowest lake level of the whole sequence (last 20,000 years) occurred from 11,600 to 9400 cal yrs BP, when full Holocene conditions were finally reached (Morellón et al., 2009a). The Lake Banyoles sequence also records the eventual decrease in steppe taxa at 9500 cal yrs BP (Pérez-Obiol and Julià, 1994). In Enol Lake record, wetter conditions were not found until 9800 cal yrs BP when Ca, TOC and TIC percentages increase while siliciclastic particles decrease (Moreno et al., in press-b). In that record, arboreal pollen values increase markedly at the onset of the Holocene, dominated by a rapid increase of deciduous Quercus (45\%), although the highest values were recorded at 9700 cal yrs BP. Accordingly, pollen records from the Alboran Sea indicate that the temperate Mediterranean forest expanded dramatically in response to increased humidity not developed at the Holocene onset but at 10,600 cal yrs BP (Fletcher et al., 2010). This delay may be related to a restricted rainy season during the boreal summer insolation maximum (Tzedakis, 2007). Thus, it seems from the available records, that the delay in the Holocene onset is related more to hydrological parameters than to temperature changes, pointing to a possible impact of the monsoon dynamics on the IP climate. 


\section{Summary and ideas for the future work}

Selected lake records show the IP response to abrupt climate changes during last glacial cycle. Although, in general, there is a synchrony and a high correlation with North Atlantic region climate, the IP presents some peculiarities likely related to its southern location and the mix of African and European influences on its climate. Thus, the transition from MIS 5 to MIS 4 appears as a cold but relatively wet period, and corresponds to the maximum glacier extension in the northern Iberian mountains (e.g., Pyrenees, Cantabrian Mountains). Subsequent deglaciation occurs rapidly, probably associated with the general tendency towards greater aridity during MIS 4, and due to abrupt climate changes that characterized the MIS 3 interval, which includes some of the most arid periods in Iberian continental records. Abrupt climate changes, particularly HE, are observed in several records by changes in the sediment and vegetation cover and composition, thus demonstrating the effect of rapid climate variability on land. The global LGM is not the coldest or the most arid interval of the last 25,000 years since the MI, and the embedded HE1 event, are characterized by the highest aridity in the studied sequences. As detected in the lake sequences, the Lateglacial period starts synchronously to temperature increase in Greenland $(14,600$ cal yrs BP), but the pattern is not so abrupt and, additionally, the highest humidity is reached at the end of GI-1 (Allerød) and not at the beginning (Bølling). Finally, the GS-1 (YD) is observed in the hydrological response of the lake records but variable signals in the pollen spectra, suggesting different sensitivity of the vegetation in different localities with respect to altitude, topography and microclimate, and possibly relating to vegetation resilience at this time. The Holocene climatic optimum in terms of humidity seems to be delayed with respect to other European records, being reached in different locations only after 10.5-9.5 cal yrs BP.

From this compilation, it is evident that a major advance has been achieved recently in terms of palaeoclimate reconstructions obtained from lake records in the IP. Many of the records that provide critical information have been published recently or are in press (Estanya Lake, Enol Lake, etc.). However, despite the increased number of new studies, several questions remain open due to the lack of high-resolution records in key geographic regions. Thus, the southern IP region was not extensively discussed in this paper due to the scarcity of multi-proxy high-resolution lake records. It is clear that more records are necessary, especially from low altitude areas, that are currently underrepresented in the compilation. The greatest effort must be made to obtain laminated records, e.g., in karstic lakes such as Banyoles Lake, that will provide better resolution permitting the detection and characterization of abrupt climate changes during the last glacial cycle. In addition, long sequences such as Villarquemado palaeolake will provide new information on climate changes during the last glacial inception and the IP LGM. It is strongly advisable to compare and combine information from lake records with those obtained from other continental palaeoarchives, particularly speleothems and glacial deposits, and terrestrial tracers in marine sediment sequences. The integration of data from different palaeoarchives is critical to developing the understanding of the response of continental Iberia to rapid climate changes during last glacial cycle.

The multi-proxy approach has been found to be the best (if not only!) option to discriminate climate changes from other more local influences on the lake records (particular response of vegetation, etc.). However, further efforts are required not only to combine indicators, but to improve their calibration with the instrumental record. Greater use of quantitative estimations of temperature and precipitation would be highly informative and this remains an under-explored approach in the IP. Proxy calibration, together with an improvement of transfer function databases, will lead to better reconstruction of climate signals and will thus also contribute to the improvement of climate models.

Finally, the construction of robust chronological frameworks is indispensable for palaeoclimate reconstruction, particularly for the characterization of rapid climate changes. More effort must be made to look for high-quality dating material (terrestrial macroremains, charcoal) suitable for ${ }^{14} \mathrm{C}$ AMS in lake sediments. In addition, other methods, such as the tephrochronology, have not been explored in the IP terrestrial records and may be worth trying despite the non-favourable situation with respect to major volcanic zones and prevailing wind directions. Comparing records with independent chronologies (i.e., not tuned respect to Greenland ice cores) is essential for the identification of leads and lags in the continental response to different climate events.

\section{Acknowledgements}

The funding for this study mainly derives from LIMNOCLIBER (REN2003-09130-C02-02), LIMNOCAL (CGL2006-13327-C04-01), GRACCIE-CONSOLIDER (CSD2007-00067) and DINAMO (CGL200907992) projects, provided by the Spanish Inter-Ministry Commission of Science and Technology (CICYT), and the VILLARQUEMADO (P196/2005) project from the Aragón Regional Government (DGA). A. Moreno acknowledges the funding from the "Ramón y Cajal" postdoctoral program. We are grateful to $\mathrm{M}^{\mathrm{a}}$ Paz Errea for his help with Fig 1 and to Juana Vegas (IGME, Madrid, Spain), Mayte Rico (IPE-CSIC, Zaragoza, Spain), Lucia de Abreu (Cambridge University, UK), and Jaume Frigola and Isabel Cacho (UB, Barcelona, Spain) for kindly providing their data. We are indebt to the organizers of INTIMATE meeting in Oxford (September 2008) where the ideas for this study originated.

\section{Appendix. Supplementary material}

Supplementary data associated with this article can be found in the online version, at doi:10.1016/j.quascirev.2010.06.031.

\section{References}

de Abreu, L., Shackleton, N.J., Schönfeld, J., Hall, M.A., Chapman, M.R., 2003. Millennial-scale oceanic climate variability off the Western Iberian margin during the last two glacial periods. Marine Geology 196, 1-20.

Allen, J.R.M., Brandt, U., Brauer, A., Hubberten, H.W., Huntley, B., Keller, J., Kraml, M., Mackensen, A., Mingram, J., Negendank, J.F.W., Nowaczyk, N.R., Oberhänsli, H., Watts, W.A., Wulf, S., Zolitschka, B., 1999. Rapid environmental changes in southern Europe during the last glacial period. Nature 400, 740-743.

Beaudouin, C., Jouet, G., Suc, J.P., Berné, S., Escarguel, G., 2007. Vegetation dynamics in southern France during the last 30 ky BP in the light of marine palynology Quaternary Science Reviews 26, 1037-1054.

Björck, S., Walker, M.J.C., Cwynar, L., Johnsen, S.J., Knudsen, K.-L., Lowe, J.J. Wohlfarth, B., INTIMATE Group, 1998. An event sratigraphy for the last termination in the North Atlantic based on the Greenland Ice core record: a proposal by the INTIMATE group. Journal of Quaternary Science 13, 283-292.

Blanco-Castro, E., Casado, M., Costa, M., Escribano, R., García-Antón, M., Génova, M., Gómez, A., Moreno, J., Morla, C., Regato, P., Sainz Ollero, H., 1997. Los bosques ibéricos. Una interpretación geobotánica. Planeta, Barcelona.

Bout-Roumazeilles, V., Combourieu Nebout, N., Peyron, O., Cortijo, E., Landais, A., Masson-Delmotte, V., 2007. Connection between South Mediterranean climate and North African atmospheric circulation during the last 50,000 yr BP North Atlantic cold events. Quaternary Science Reviews 26, 3197-3215.

Broecker, W.S., 2000. Abrupt climate change: causal constraints provided by the paleoclimate record. Earth-Science Reviews 51, 137-154.

Burjachs, F., Julià, R., 1994. Abrupt climatic changes during the last glaciation based on pollen analysis of the Abric Romani, Catalonia, Spain. Quaternary Research 42, 308-315.

Cabrera, L., Anadón, P., 2003. Desarrollo de los proyectos IGCP 219 y 324 (GLOPALSGGLAB) en España: Kerry Kelts como elemento dinamizador. In: ValeroGarcés, B. (Ed.), Limnogeology in Spain: A Tribute to Kerry Kelts. Consejo Superior de Investigaciones Científicas, Madrid, pp. 37-59.

Cacho, I., Grimalt, J.O., Canals, M., Sbaffi, L., Shackleton, N.J., Schönfeld, J., Zahn, R., 2001. Variability of the Western Mediterranean sea surface temperatures 
during the last 25,000 years and its connection with the northern hemisphere climatic changes. Paleoceanography $16,40-52$.

Cacho, I., Grimalt, J.O., Pelejero, C., Canals, M., Sierro, F.J., Flores, J.A., Shackleton, N.J., 1999. Dansgaard-Oeschger and Heinrich event imprints in Alboran Sea temperatures. Paleoceanography 14, 698-705.

Capel Molina, J.J., 1981. Los climas de España. Oikos-tau ediciones, Barcelona.

Carrión, J.S., 2002. Patterns and processes of Late Quaternary environmental change in a montane region of southwestern Europe. Quaternary Science Reviews 21, 2047-2066.

Carrión, J.S., Fernández, S., González-Sampériz, P., Gil-Romera, G., Badal, E., CarriónMarco, Y., López-Merino, L., López-Sáez, J.A., Burjachs, F., Expected trends and surprises in the Lateglacial and Holocene vegetation history of the Iberian Peninsula and Balearic Islands. Review of Palaeobotany and Palynology, in press (doi:10.1016/j.revpalbo.2009.12.007).

Clark, P.U., Dyke, A.S., Shakun, J.D., Carlson, A.E., Clark, J., Wohlfarth, B., Mitrovica, J.X., Hostetler, S.W., McCabe, A.M., 2009. The last glacial maximum. Science 325, 710-714.

Cohen, A.S., 2003. Paleolimnology. The History and Evolution of Lake Systems. Oxford University Press, New York.

Combourieu Nebout, N., Peyron, O., Dormoy, I., Desprat, S., Beaudouin, C. Kotthoff, U., Marret, F., 2009. Rapid climatic variability in the west Mediterranean during the last 25000 years from high resolution pollen data. Climate of the Past 5, 503-521.

Combourieu Nebout, N., Turon, J.L., Zahn, R., Capotondi, L., Londeix, L., Pahnke, K. 2002. Enhanced aridity and atmospheric high-pressure stability over the western Mediterranean during the North Atlantic cold events of the past 50 k.y. Geology 30, 863-866.

Corella, J.P., Valero-Garcés, B.L., Moreno, A., Morellón, M., Rull, V., Giralt, S., Rico, M.T., Pérez-Sanz, A., Sedimentary evolution and palaeohydrology of karstic, meromictic Montcortés Lake (Spanish Pre-Pyrenees) during the last 6,000 years. Journal of Paleolimnology, in press (doi:10.1007/s10933-010-9443-3).

Costanza, R., Graumlich, L., Steffen, W., Crumley, C., Dearing, J., Hibbard, K., Leemans, R., Redman, C., Schimel, D., 2007. Sustainability or collapse: what can we learn from integrating the history of humans and the rest of nature? Ambio 36, 522-527.

Cheng, H., Edwards, R.L., Wang, Y., Kong, X., Ming, Y., Kelly, M.J., Wang, X. Gallup, C.D., 2006. A penultimate glacial monsoon record from Hulu Cave and two-phase glacial terminations. Geology 34, 217-220.

Denton, G.H., Alley, R.B., Comer, G.C., Broecker, W.S., 2005. The role of seasonality in abrupt climate change. Quaternary Science Reviews 24, 1159-1182.

Denton, G.H., Broecker, W., Alley, R.B., 2006. The mystery interval 17.5 to $14.5 \mathrm{kyr}$ ago. In: Brigham-Grette, J., Kull, C., Kiefer, T. (Eds.), PAGES News, pp. 14-16.

Farias-Arquer, P., Jiménez Sánchez, M., Martínez, J., 1996. Nuevos datos sobre la estratigrafía del relleno cuaternario de la depresión de Comeya, Picos de Europa, Asturias. Geogaceta 20, 2016-2019.

Fletcher, W.J., Sánchez-Goñi, M.F., 2008. Orbital- and sub-orbital-scale climate impacts on vegetation of the western Mediterranean basin over the last 48,000 yr. Quaternary Research 70, 451-464.

Fletcher, W.J., Sánchez-Goñi, M.F., Allen, J.R.M., Cheddadi, R., Combourieu Nebout, N., Huntley, B., Lawson, I., Londeix, L., Magri, D., Margari, V., Müller, U.C. Naughton, F., Novenko, E., Roucoux, K., Tzedakis, P.C., 2010. Millennial-scale variability during the last glacial in vegetation records from Europe. Quaternary Science Reviews 29, 2839-2864.

Fletcher, W.J., Sánchez-Goñi, M.F., Peyron, O., Dormoy, I., 2010. Abrupt climate changes of the last deglaciation detected in a western Mediterranean forest record. Climate of the Past 6, 245-264.

Frigola, J., Moreno, A., Cacho, I., Canals, M., Sierro, F.J., Flores, J.A., Grimalt, J.O., 2008 Evidence of abrupt changes in Western Mediterranean Deep Water circulation during the last 50 kyr: a high-resolution marine record from the Balearic Sea. Quaternary International 181, 88-104.

Fritz, S.C., 2008. Deciphering climate history from lake sediments. Journal of Paleolimnology 39, 5-16.

García-Ruíz, J.M., Moreno, A., González-Sampériz, P., Valero-Garcés, B., MartíBono, C., 2010. La cronología del último ciclo glaciar en las montañas del sur de Europa. Una revisión. Cuaternario y Geomorfología. 24, 35-46.

García-Ruíz, J.M., Valero-Garcés, B.L., Martí-Bono, C., González-Sampériz, P., 2003. Asynchroneity of maximum glacier advances in the central Spanish Pyrenees. Journal of Quaternary Science 18, 61-72.

Genty, D., Blamart, D., Ghaleb, B., Plagnes, V., Causse, Ch., Bakalowicz, M., Zouari, K. Chkir, N., Hellstrom, J., Wainer, K., Bourges, F., 2006. Timing and dynamics of the last deglaciation from European and North African $\delta^{13} \mathrm{C}$ stalagmite profiles-comparison with Chinese and South Hemisphere stalagmites. Quaternary Science Reviews 25, 2118-2142.

Gibbons, W., Moreno, T., 2002. The Geology of Spain. The Geological Society, London.

Gil-Romera, G., López-Merino, L., Carrión, J.S., González-Sampériz, P., MartínPuertas, C., Sáez, J.A.L., Fernández, S., Antón, M.G., Stefanova, V., 2010. Interpreting resilience through long-term ecology: potential insights in western Mediterranean landscapes. The Open Ecology Journal 2010 (3), 43-53.

Gillespie, A., Molnar, P., 1995. Asynchronous maximum advances of mountain and continental glaciers. Reviews of Geophysics 33, 311-364.

Gómez-Orellana, L., Ramil-Rego, P., Muñoz Sobrino, C., 2007. The Würm in NW Iberia, a pollen record from Area Longa (Galicia). Quaternary Research 67, $438-452$.
González-Sampériz, P., Leroy, S.A.G., Fernández, S., García-Antón, M., Gil-García, M.J., Uzquiano, P., Valero-Garcés, B., Figueiral, I., Steppes, savannahs, forests and phytodiversity reservoirs during the Pleistocene in the Iberian Peninsula. Review of Palaeobotany and Palynology, in press (doi:10.1016/j.revpalbo.2010. 03.009).

González-Sampériz, P., Valero-Garcés, B.L., Carrión, J.S., Peña-Monné, J.L., GarcíaRuíz, J.M., Martí-Bono, C., 2005. Glacial and Lateglacial vegetation in northeastern Spain: new data and a review. Quaternary International 140-141, $4-20$.

González-Sampériz, P., Valero-Garcés, B.L., Moreno, A., Jalut, G., García-Ruiz, J.M., Martí-Bono, C., Delgado-Huertas, A., Navas, A., Otto, T., Dedoubat, J.J., 2006. Climate variability in the Spanish Pyrenees during the last 30,000 yr revealed by the El Portalet sequence. Quaternary Research 66, 38-52.

Gonzalez-Samperiz, P., Valero-Garces, B.L., Moreno, A., Morellon, M., Navas, A., Machin, J., Delgado-Huertas, A., 2008. Vegetation changes and hydrological fluctuations in the Central Ebro Basin (NE Spain) since the Late Glacial period: saline lake records. Palaeogeography, Palaeoclimatology, Palaeoecology 259, 157-181.

Heegaard, E., Birks, H.J.B., Telford, R.J., 2005. Relationships between calibrated ages and depth in stratigraphical sequences: an estimation procedure by mixedeffect regression. The Holocene 15, 612-618.

Hoek, W.Z., Yu, Z.C., Lowe, J.J., 2008. INTegration of Ice-core, MArine, and TErrestrial records (INTIMATE): refining the record of the Last Glacial-Interglacial transition. Quaternary Science Reviews 27, 1-5.

Hughen, K.A., Southon, J.R., Lehman, S.J., Overpeck, J.T., 2000. Synchronous radiocarbon and climate shifts during the last deglaciation. Science 290, 1951-1954.

Hughes, P.D., Woodward, J.C., 2008. Timing of glaciation in the Mediterranean mountains during the last cold stage. Journal of Quaternary Science 23, 575-588.

Jiménez-Espejo, F.J., Martínez-Ruiz, F., Sakamoto, T., Ijima, K., Gallego-Torres, D., Harada, N., 2007. Paleoenvironmental changes in the western Mediterranean since the last glacial maximum: high resolution multiproxy record from the Algero-Balearic basin. Palaeogeography, Palaeoclimatology, Palaeoecology 246 , 292-306.

Jiménez Sánchez, M., Farias, P., 2002. New radiometric and geomorphologic evidences of a last glacial maximum older than $18 \mathrm{ka}$ in SW European mountains: the example of Redes Natural Park (Cantabrian Mountains, NW Spain). Geodinamica Acta 15, 93-101.

Kageyama, M., Combourieu Nebout, N., Sepulchre, P., Peyron, O., Krinner, G., Ramstein, G., Cazet, J.-P., 2005. The Last Glacial Maximum and Heinrich Event 1 in terms of climate and vegetation around the Alboran Sea: a preliminary model-data comparison. Comptes Rendues a l'Acadèmie des Sciences de Paris 337, 983-992.

Lebreiro, S.M., Moreno, J.C., McCave, I.N., Weaver, P.P.E., 1996. Evidence for Heinrich layers off Portugal (Tore Seamount: $39^{\circ} \mathrm{N}, 12^{\circ} \mathrm{W}$ ). Marine Geology 131, 47-56.

Leira, M., 2005. Diatom responses to Holocene environmental changes in a small lake in northwest Spain. Quaternary International 140-141, 90-102.

Lewis, C.J., McDonald, E.V., Sancho, C., Peña, J.L., Rhodes, E.J., 2009. Climatic implications of correlated Upper Pleistocene glacial and fluvial deposits on the Cinca and Gállego Rivers (NE Spain) based on OSL dating and soil stratigraphy. Global and Planetary Change 67, 141-152.

Lowe, J.J., Rasmussen, S.O., Björck, S., Hoek, W.Z., Steffensen, J.P., Walker, M.J.C., Yu, Z.C., 2008. Synchronisation of palaeoenvironmental events in the North Atlantic region during the last termination: a revised protocol recommended by the INTIMATE group. Quaternary Science Reviews 27, 6-17.

Magny, M., 2001. Palaeohydrological changes as reflected by lake-level fluctuations in the Swiss Plateau, the Jura Mountains and the northern French Pre-Alps during the Last Glacial-Holocene transition: a regional synthesis. Global and Planetary Change 30, 85-101.

Magny, M., de Beaulieu, J.-L., Drescher-Schneider, R., Vannière, B., WalterSimonnet, A.-V., Millet, L., Bossuet, G., Peyron, O., 2006. Climatic oscillations in central Italy during the Last Glacial-Holocene transition: the record from Lake Accesa. Journal of Quaternary Science 21, 311-320.

Mangerud, J., Andersen, S.T., Berglund, B.E., Donner, J.J., 1974. Quaternary stratigraphy of Norden, a proposal for terminology and classification. Boreas 4, 109-128.

Martín-Puertas, C., Valero-Garcés, B.L., Mata, P., González-Sampériz, P., Bao, R. Moreno, A., Stefanova, V., 2008. Arid and humid phases in Southern Spain during the last 4000 years: the Zoñar Lake record, Córdoba. The Holocene 40, 195-215.

Martrat, B., Grimalt, J.O., Lopez-Martinez, C., Cacho, I., Sierro, FJ., Flores, J.A. Zahn, R., Canals, M., Curtis, J.H., Hodell, D.A., 2004. Abrupt temperature changes in the Western Mediterranean over the past 250000 years. Science 306, $1762-1765$.

Masson-Delmotte, V., Landais, A., Combourieu Nebout, N., von Grafenstein, U., Jouzel, J., Caillon, N., Chappellaz, J., Dahl-Jensen, D., Johnsen, S.J., Stenni, B., 2005. Rapid climate variability during warm and cold periods in polar regions and Europe. Comptes Rendus Geosciences 337, 935-946.

McManus, J., Francois, R., Gherardi, J.M., Keigwin, L., Brown-Leger, S., 2004. Collapse and rapid resumption of Atlantic meridional circulation linked to deglacial climate changes. Nature 428, 834-837.

Mix, A.C., Bard, E., Schneider, R., 2001. Environmental processes of the ice age: land, oceans, glaciers (EPILOG). Quaternary Science Reviews 20, 627-657. 
Montserrat, J., 1992. Evolución glaciar y postglaciar del clima y la vegetación en la vertiente sur del Pirineo: estudio palinológico. Instituto Pirenaico de Ecología, Zaragoza.

Morellón, M., 2009. Paleohydrology and Abrupt Climate Changes in Northeastern Iberian Peninsula During the last 20,000 Years: The Lacustrine Record of Estanya (Huesca). Earth Sciences Department, University of Zaragoza, Zaragoza, p. 323.

Morellón, M., Valero-Garcés, B., González-Sampériz, P., Vegas-Vilarrúbia, T., Rubio, E., Rieradevall, M., Delgado-Huertas, A., Mata, P., Romero, Ó., Engstrom, D.R., López-Vicente, M., Navas, A., Soto, J., Climate and human signatures during the Medieval Warm Period and the Little Ice Age in the Spanish Pre-Pyrenees: the Lake Estanya record. Journal of Paleolimnology, in press (doi:10.1007/s10933009-9346-3).

Morellón, M., Valero-Garcés, B., Vegas-Vilarrúbia, T., González-Sampériz, P., Romero, Ó., Delgado-Huertas, A., Mata, P., Moreno, A., Rico, M., Corella, J.P., 2009a. Lateglacial and Holocene palaeohydrology in the western Mediterranean region: the Lake Estanya record (NE Spain). Quaternary Science Reviews 28, 2582-2599.

Morellón, M., Valero-Garcés, B.L., Anselmetti, F., Ariztegui, D., Schnellmann, M., Moreno, A., Mata, P., Rico, M., Corella, J.P., 2009b. Late Quaternary deposition and facies model for karstic Lake Estanya (NE Spain). Sedimentology 56, 1505-1534.

Moreno, A., Cacho, I., Canals, M., Grimalt, J.O., Sánchez-Goñi, M.F., Shackleton, N.J. Sierro, F.J., 2005. Links between marine and atmospheric processes oscillating at millennial time-scale. A multy-proxy study of the last 50,000 yr from the Alboran Sea (Western Mediterranean Sea). Quaternary Science Reviews 24, 1623-1636.

Moreno, A., Cacho, I., Canals, M., Prins, M.A., Sánchez-Goñi, M.F., Grimalt, J.O., Weltje, G.J., 2002. Saharan dust transport and high latitude glacial climatic variability: the Alboran Sea record. Quaternary Research 58, 318-328.

Moreno, A., Stoll, H.M., Jiménez Sánchez, M., Cacho, I., Valero-Garcés, B., Ito, E., Edwards, L.R., 2010. A speleothem record of rapid climatic shifts during last glacial period from Northern Iberian Peninsula. Global and Planetary Change 71, 218-231. doi:10.1016/j.gloplacha.2009.1010.1002.

Moreno, A., Valero-Garcés, B.L., Jiménez Sánchez, M., Domínguez, M.J., Mata, P., Navas, A., González-Sampériz, P., Stoll, H., Farias, P., Morellón, M., Corella, P., Rico, M., The last deglaciation in the Picos de Europa National Park (Cantabrian Mountains, Northern Spain). Journal of Quaternary Science, in press-a (doi:10. 1002 jqs.1265).

Moreno, A., López-Merino, L., Leira, M., Marco-Barba, J., González-Sampériz, P., Valero-Garcés, B., López-Sáez, J.A., Santos, L., Mata, P., Ito, E., Revealing the last 13,500 years of environmental history from the multiproxy record of a mountain lake (Lago Enol, northern Iberian Peninsula). Journal of Paleolimnology, in press-b (doi:10.1007/s10933-10009-19387-10937).

Naughton, F., Sánchez-Goñi, M.F., Desprat, S., Turon, J.L., Duprat, J., Malaize, B., Joli, C., Cortijo, E., Drago, T., Freitas, M.C., 2007. Present-day and past (last 25000 years) marine pollen signal off western Iberia. Marine Micropaleontology 62, 91-114.

Naughton, F., Sánchez-Goñi, M.F., Kageyama, M., Bard, E., Duprat, J., Cortijo, E., Desprat, S., Malaizé, B., Joly, C., Rostek, F., Turon, J.L., 2009. Wet to dry climatic trend in north-western Iberia within Heinrich events. Earth and Planetary Science Letters 284, 329-342.

NGRIP Members, 2004. High-resolution record of Northern Hemisphere climate extending into the last interglacial period. Nature 431, 147-151.

Ortiz, J., Torres, T., Delgado-Huertas, A., Julià, R., Lucini, M., Llamas, F.J., Reyes, E., Soler, V., Valle, M., 2004. The palaeoenvironmental and palaeohydrological evolution of Padul Peat Bog (Granada, Spain) over one million years, from elemental, isotopic and molecular organic geochemical proxies. Organic Geochemistry 35, 1243-1260.

Pallàs, R., Rodés, Á., Braucher, R., Carcaillet, J., Ortuño, M., Bordonau, J., Bourlès, D., Vilaplana, J., Masana, E., Santanach, P., 2006. Late Pleistocene and Holocene glaciation in the Pyrenees: a critical review and new evidence from ${ }^{10} \mathrm{Be}$ exposure ages, south-central Pyrenees. Quaternary Science Reviews 25, 2937-2963.

Peña, J.L., Sancho, C., Lewis, C., McDonald, E., Rhodes, E., 2003. Las morrenas terminales de los valles glaciares del Gállego y Cinca (Pirineo de Huesca). Datos cronológicos. Boletín Glaciológico Aragonés 4, 91-109.

Pérez-Folgado, M., Sierro, F.J., Flores, J.A., Grimalt, J.O., Zahn, R., 2004. Paleoclimatic variations in foraminifer assemblages from the Alboran Sea (Western Mediterranean) during the last $150 \mathrm{ka}$ in ODP Site 977. Marine Geology 212, $113-131$.

Pérez-Obiol, R., Julià, R., 1994. Climate change on the Iberian Peninsula recorded in a 30.000 yr pollen record from Lake Banyoles. Quaternary Research 41, 91-98.

Pons, A., Reille, M., 1988. The Holocene and upper Pleistocene pollen record from Padul (Granada, Spain): a new study. Palaeogeography, Palaeoclimatology, Palaeoecology 66, 243-263.

Rasmussen, S.O., Andersen, K.K., Svensson, A., Steffensen, J.P., Vinther, B.M., Clausen, H.B., Siggaard-Andersen, M.L., Johnsen, S.J., Larsen, L.B., Dahl-Jensen, D., Bigler, M., Röthlisberger, R., Fisher, H., Goto-Azuma, K., Hansson, M., Ruth, U., 2006. A new Greenland ice core chronology for the last glacial termination. Journal of Geophysical Research 11 (doi:10.1029/2005JD006079).

Reimer, P., Baillie, M., Bard, E., Bayliss, A., Beck, J., Blackwell, P., Bronk Ramsey, C., Buck, C., Burr, G., Edwards, R., Friedrich, M., Grootes, P., Guilderson, T., Hajdas, I. Heaton, T., Hogg, A., Hughen, K., Kaiser, K., Kromer, B., McCormac, F., Manning, S., Reimer, R., Richards, D., Southon, J., Talamo, S., Turney, C., van der
Plicht, J., Weyhenmeyer, C., 2009. IntCal09 and Marine09 radiocarbon age calibration curves, 0-50,000 years cal BP. Radiocarbon 51, 1111-1150.

Rico, M., Garcés, B.V., Vega, J.C., Moreno, A., González-Sampériz, P., Morellón, M. Mata, P., 2007. El registro del Lago de Sanabria desde la última deglaciación, XI Reunión Nacional de Cuaternario. In: Lario, J., Silva, P.G. (Eds.). AEQUA, Ávila, pp. 213-214.

Rivas-Martínez, S., 2007. Mapa de series, geoseries y geopermaseries de vegetación de España. Memoria del mapa de la vegetación potencial de España. Itineraria Geobotanica 17, 1-436.

Roucoux, K.H., de Abreu, L., Shackleton, N.J., Tzedakis, C., 2005. The response of NW Iberian vegetation to North Atlantic climate oscillations during the last $65 \mathrm{kyr}$ Quaternary Science Reviews 24, 1637-1653.

Roucoux, K.H., Shackleton, N.J., de Abreu, L., Schönfeld, J., Tzedakis, C., 2001 Combined marine proxy and pollen analyses reveal rapid Iberian vegetation response to North Atlantic millennial-scale climate oscillations. Quaternary Research 56, 128-132.

Rull, V., González-Sampériz, P., Valero-Garcés, B., Corella, P., Morellón, M., Vegetation changes in the southern Pyrenean flank during the last millennium in relation to climate and human activities: the Montcortès lacustrine record. Journal of Paleolimnology, in press (doi:10.1007/s10933-010-9444-2).

Sánchez-Goñi, M.F., Turon, J.L., Eynaud, F., Gendreau, S., 2000. European climatic response to millenial-scale changes in the atmosphere-ocean system during the Last Glacial period. Quaternary Research 54, 394-403.

Sánchez-Goñi, M.F., Cacho, I., Turon, J.L., Guiot, J., Sierro, F.J., Peypouquet, J.-P. Grimalt, J.O., Shackleton, N.J., 2002. Synchroneity between marine and terrestrial responses to millennial scale climatic variability during the last glacial period in the Mediterranean region. Climate Dynamics 19, 95-105.

Sánchez-Goñi, M.F., Loutre, M.F., Crucifix, M., Peyron, O., Santos, L., Duprat, J. Malaizé, B., Turon, J.L., Peypouquet, J.P., 2005. Increasing vegetation and climate gradient in Western Europe over the Last Glacial Inception (122-110 ka): datamodel comparison. Earth and Planetary Science Letters 231 (1, 2), 111-130.

Sánchez-Goñi, M.F., Landais, A., Fletcher, W.J., Naughton, F., Desprat, S., Duprat, J., 2008. Contrasting impacts of Dansgaard-Oeschger events over a western European latitudinal transect modulated by orbital parameters. Quaternary Science Reviews 27, 1136-1151.

Sancho-Marcén, C., Peña-Monné, J.L., Lewis, C., McDonald, E., Rhodes, E., 2003. Preliminary dating of glacial and fluvial deposits in the Cinca river Valley (NE Spain): chronological evidences for the Glacial Maximum in the Pyrenees? In: Ruiz Zapata, B., Dorado-Valiño, M., Valdeomillos, A., Gil-García, M.J., Bardají, T. Bustamante, I., Mendizábal, I. (Eds.), Quaternary Climatic Changes and Environmental Crises in The Mediterranean Region. Alcalá de Henares, Madrid, pp. 169-174.

Schnurrenberger, D.W., Kelts, K., Johnson, T.C., Shane, L.C.K., Ito, E., 2001. National lacustrine core repository (LacCore). Journal of Paleolimnology 25, 123-127.

Solomon, S., Qin, D., Manning, M., Chen, Z., Marquis, M., Averyt, K.B., Tignor, M. Miller, H.L., 2007. Climate change 2007: the physical science basis. Contribution of Working Group I to the Fourth Assessment Report of the Intergovernmental Panel on Climate Change. Cambridge University Press, Cambridge, UK.

Svendsen, J.I., Alexanderson, H., Astakhov, V.I., Demidov, I., Dowdeswell, J.A. Funder, S., Gataullin, V., Henriksen, M., Hjort, C., Houmark-Nielsen, M. Hubberten, H.W., Ingólfsson, Ó., Jakobsson, M., Kjær, K.H., Larsen, E. Lokrantz, H., Lunkka, J.P., Lyså, A., Mangerud, J., Matiouchkov, A., Murray, A. Möller, P., Niessen, F., Nikolskaya, O., Polyak, L., Saarnisto, M., Siegert, C. Siegert, M.J., Spielhagen, R.F., Stein, R., 2004. Late Quaternary ice sheet history of northern Eurasia. Quaternary Science Reviews 23, 1229-1271.

Tzedakis, C., McManus, J., Hooghiemstra, H., Oppo, D.W., Wijmstra, T.A., 2003. Comparison of changes in vegetation in northeast Greece with records of climate variability on orbital and suborbital frequencies over the last 450000 years. Earth and Planetary Science Letters 212, 197-212.

Tzedakis, P.C., 2007. Seven ambiguities in the Mediterranean palaeoenvironmental narrative. Quaternary Science Reviews 26, 2042-2066.

Valero-Garcés, B., González-Sampériz, P., Navas, A., Machín, J., Delgado-Huertas, A Peña-Monné, J.L., Sancho-Marcén, C., Stevenson, T., Davis, B., 2004. Palaeohydrological fluctuations and steppe vegetation during the Last Glacial Maximum in the central Ebro valley (NE Spain). Quaternary International 122, 43-55.

Valero-Garcés, B., González-Sampériz, P., Morellón, M., Rico, M., Moreno, A., Navas, A., Machín, J., Mata, M.P., Rubio, J.C., 2007. Climate and Tectonics for the last 100 kyrs in the Iberian Range (NE Spain) based on the Villarquemado Lacustrine Record. Fourth International Limnogeology Congress, Barcelona, Spain.

Valero-Garcés, B., Moreno, A., Iberian lacustrine records: responses to past and recent global changes in the Mediterranean region. Journal of Paleolimnology Special Volume, in press.

Valero-Garcés, B., Navas, A., Mata, P., Delgado-Huertas, A., Machín, J., GonzálezSampériz, P., Moreno, A., Schwalb, A., Ariztegui, D., Schnellmann, M., Bao, R. González-Barrios, A., 2003. Sedimentary facies analyses in lacustrine cores: from initial core descriptions to detailed palaeoenvironmental reconstructions. A case study from Zoñar Lake (Cordoba province, Spain). In: Valero-Garcés, B. (Ed.), Limnogeology in Spain: A Tribute to Kerry Kelts. C.S.I.C., Madrid, pp. 385-414.

Valero-Garcés, B.L., 2003. Limnologeología en España: un tributo a Kerry Kelts/ Limnogeology in Spain: a tribute to Kerry Kelts. Biblioteca de Ciencias. Consejo Superior de Investigaciones Científicas, Madrid, p. 438.

Valero-Garcés, B.L., Zeroual, E., Kelts, K., 1998. Arid phases in the western Mediterranean region during the last glacial cycle reconstructed from lacustrine 
records. In: Benito, G., Baker, V.R., Gregory, K.J. (Eds.), Paleohydrology and Environmental Change, pp. 67-80.

Vegas, J., 2006. Los sistemas lacustres de las Sierras de Neila y Urbión: análisis sedimentológico y climático del Pleistoceno Superior y Holoceno. Departamento de Petrología y Geoquímica. Universidad Complutense de Madrid, Madrid, p. 387.

Vegas, J., 2007. Caracterización de eventos climáticos del Pleistoceno superiorHoloceno mediante el estudio sedimentológico de la Laguna Grande (Sierra Neila, NO Sistema Ibérico). Revista de la Sociedad Geológica de España 20, 53-70.

Vegas, J., Blanca Ruiz Zapata, M., Ortiz, J.E., Galán, L., Torres, T., García-Cortés, A., GilGarcía, M.J., Pérez-González, A., Gallardo-Millán, J.L., Identification of arid phases during the last $50 \mathrm{ca}$. ka BP from Fuentillejo maar-lacustrine record (Campo de Calatrava Volcanic Field, Spain). Journal of Quaternary Science, in press (doi:10.1002/jqs.1262).
Vegas, J., Pérez-González, A., Ruiz Zapata, B., Gil-García, M.J., Dorado, M., Valdeolmillos, A., López-García, M.J., 2003. The GS-1/Younger Dryas Event in the Laguna Grande lacustrine record. Lateglacial-Holocene transition in the NW Iberian Range, Spain. In: Valero-Garcés, B. (Ed.), Limnogeology in Spain: A Tribute to Kerry Kelts. Biblioteca de Ciencias, CSIC, Madrid, pp. 284-304.

Vera, J.A., 2004. Geología de España. Instituto Geológico y Minero, Madrid, España, p. 884.

Wohlfarth, B., Veres, D., Ampel, L., Lacourse, T., Blaauw, M., Preusser, F., AndrieuPonel, V., Kéravis, D., Lallier-Vergès, E., Björck, S., Davies, S.M., de Beaulieu, J.-L., Risberg, J., Hormes, A., Kasper, H.U., Possnert, G., Reille, M., Thouveny, N., Zander, A., 2008. Rapid ecosystem response to abrupt climate changes during the last glacial period in western Europe, 40-16 kyr. Geology 36, 407-410.

Wolff, E.W., Chappellaz, J., Blunier, T., Rasmussen, S.O., Svensson, A., 2010. Millennial-scale variability during the last glacial: The ice core record. Quaternary Science Reviews 29, 2828-2838. 